\title{
In silico scaffold evaluation and solid phase approach to identify new gelatinase inhibitors
}

\author{
Alessandra Topai ${ }^{\mathrm{a}, *}$, Perla Breccia ${ }^{\mathrm{b}}$, Franco Minissi ${ }^{\mathrm{a}}$, Alessandro Padova ${ }^{\mathrm{c}}$, Stefano Marini ${ }^{\mathrm{d}}$, \\ Ilaria Cerbara ${ }^{\text {a }}$ \\ ${ }^{a}$ Colosseum Combinatorial Chemistry Centre for Technology (C4T S.C.a r.l.), Via della Ricerca Scientifica s.n.c., I-00133 Rome, Italy \\ ${ }^{\mathrm{b}}$ BioFocus, Chesterford Research Park, UK-CB10 1XL Saffron Walden, United Kingdom \\ ${ }^{\text {c } M o l e c u l a r ~ I n f o r m a t i c s ~ D e p t, ~ S i e n a ~ B i o t e c h ~ S . p . A ., ~ S t r a d a ~ d e l ~ P e t r i c c i o ~ e ~ B e l r i g u a r d o, ~ 35, ~ I-53100 ~ S i e n a, ~ I t a l y ~}$ \\ ${ }^{\mathrm{d}}$ Department of Experimental Medicine and Biochemical Sciences, University of Roma Tor Vergata, Via Montpellier 1, I-00133 Roma, Italy
}

\section{A R T I C L E I N F O}

\section{Article history:}

Received 13 October 2011

Revised 2 February 2012

Accepted 3 February 2012

Available online 13 February 2012

\section{Keywords:}

Matrix metalloproteinases

Gelatinase inhibitors

Solid phase synthesis

Pyroglutammate

Thioproline

\begin{abstract}
A B S T R A C T
Among matrix metalloproteinases (MMPs), gelatinases MMP-2 (gelatinase A) and MMP-9 (gelatinase B) play a key role in a number of physiological processes such as tissue repair and fibrosis. Many evidences point out their involvement in a series of pathological events, such as arthritis, multiple sclerosis, cardiovascular diseases, inflammatory processes and tumor progression by degradation of the extracellular matrix. To date, the identification of non-specific MMP inhibitors has made difficult the selective targeting of gelatinases. In this work we report the identification, design and synthesis of new gelatinase inhibitors with appropriate drug-like properties and good profile in terms of affinity and selectivity. By a detailed in silico protocol and innovative and versatile solid phase approaches, a series of 4-thiazolydinyl- $N$-hydroxycarboxyamide derivatives were identified. In particular, compounds 9a and 10a showed a potent inhibitory activity against gelatinase B and good selectivity over the other MMP considered in this study. The identified compounds could represent novel potential candidates as therapeutic agents.
\end{abstract}

(c) 2012 Elsevier Ltd. All rights reserved.

\section{Introduction}

Matrix metalloproteinases (MMPs) are a family of approximately 27 zinc-dependent endopeptidases, involved in the proteolytic processing of several components of the extracellular matrix (ECM), such as collagen, proteoglycans and fibronectin.

In the last decades, considerable evidences have highlighted the involvement of abnormal MMP expression in several pathological conditions. In particular, MMP-2 and MMP-9, main enzymes able to degrade type IV collagen and gelatin, have been demonstrated to be directly involved in endothelial cell migration and vascular remodeling during angiogenesis, in tumor cell growth and progression during metastasis.

In the last twenty years, the blockage of the extracellular matrix degrading activities of MMPs has been considered an attractive strategy to treat a broad spectrum of diseases including cancer, neurological diseases, arthritis and cardiovascular pathologies. ${ }^{1-3}$ Moreover, although several potent MMPIs have been discovered, ${ }^{4-8}$ the serious dose-limiting side effects occurring in clinical trials, ${ }^{9-11}$ probably due to the non-selective inhibitory activity, have underlined the importance to identify novel inhibitors able to discriminate among MMPs. ${ }^{12,13}$ In this scenario, the selective

\footnotetext{
* Corresponding author. Tel.: +39 0672594029; fax: +39 0672594031.

E-mail address: alessandra.topai@uniroma2.it (A. Topai).
}

inhibition of gelatinases may provide confidence for a successful clinical trial, targeting acute cardiovascular diseases and tumor progression. ${ }^{14-16}$ In particular MMP-2 is considered to be a better candidate target for anticancer drugs than MMP-9, whose inhibition is related to greater drug side effects. ${ }^{17,18}$

In this paper we describe the identification of novel and selective gelatinase inhibitors by an in silico rational drug design approach and a versatile solid phase synthetic strategy. Starting from the MMP-2 complexes available in the Protein Data Bank (PDB), ${ }^{19}$ an active site mapping of gelatinase A was performed to generate the pharmacophore model used for the in silico screening of our in-house small molecule database. The screening was then followed by rational compound selection based on criteria, such as physico-chemical properties, ADMET predictions and synthetic feasibility. The computational approach led to the identification of the pyroglutamic moiety (Fig. 1) as a promising scaffold for the design and optimization of novel gelatinase inhibitors. By rational structure optimization, 4-thiazolydinyl- $N$-hydroxycarboxyamide

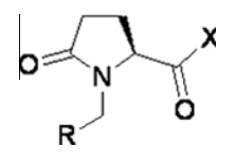

Figure 1. The pyroglutamic scaffold. 
derivatives were identified as novel potential class of gelatinase inhibitors.

\section{Results and discussion}

\subsection{MMP-2 binding site mapping and pharmacophore generation}

The design of new gelatinase inhibitors started with the recognition of the representative examples of gelatinase complexes in the PDB. Focusing on MMP-2 structures in complex with inhibitors of known potency, the 11 NMR solution structures of MMP-2 catalytic domain (cd) (pdb code: 1hov) complexed with SC-74020 (MMP-2 $\mathrm{IC}_{50}$ less than $0.1 \mathrm{nM}$ ) and the crystal structure of cdMMP-2 (pdb code: 1qib) were selected for this work.

Overlay studies were carried out in order to identify inhibitor key features, required for protein recognition and thus significant for the pharmacophore model generation. The alignment, performed with a combinatorial extension (CE) algorithm, ${ }^{20}$ showed a good overlay between the 11 NMR complexes and X-ray structure (RMSD in the range of 1.6-1.9 $\AA$ (Fig. 2a). Moreover, no significant difference in the binding mode of SC-74020, retrieved from the NMR complex with the lower RMSD with respect to 1qib structure (structure No. 7), was observed when the ligand was docked into the catalytic site of MMP-2 X-ray structure. As shown in Figure $2 \mathrm{~b}$, the hydroxamate zinc binding group (ZBG) is coordinated to $\mathrm{Zn}^{2+}$ ion, together with the catalytic histidine, while the $\mathrm{P}_{1}^{\prime}$ group is involved in hydrophobic interactions with the amino acids of $\mathrm{S}_{1}^{\prime}$ subsite, comprising a structurally stable hydrophobic pocket able to bind drug molecules at that position. According to the observed results, the more accurate MMP-2 X-ray structure was selected for further docking simulations.

By using MOE package software ${ }^{21}$ (see Section 5 for details), the selected SC-74020 NMR conformation was used to develop a pharmacophore model to mine novel and potential gelatinase inhibitors from our in-house virtual database, named MoDa. As shown in Figure 3, we considered two key pharmacophoric features: the ZBG and the $\mathrm{P}_{1}^{\prime}$ moiety, which represent the two known binding and stabilizing interactions with the molecular target. In order to identify new scaffolds to be used for further investigations and

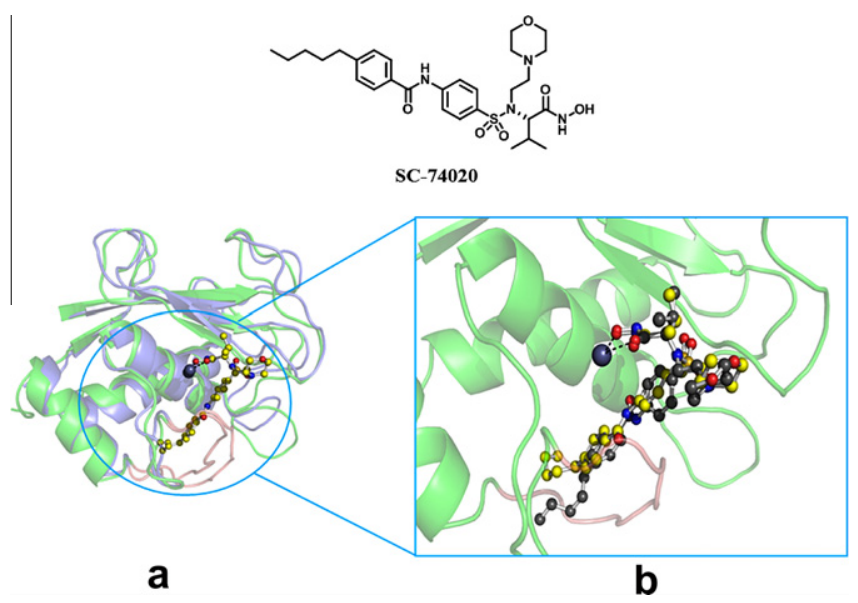

Figure 2. (a) Superimposition of NMR complex and X-ray MMP-2 structures, represented by blue and green cartoons, respectively. $S_{1}^{\prime}$ pocket is shown in pink while zinc ion is rendered as a light-gray sphere. The figure shows the NMR solution (No. 7 of 1 hov.pdb) with lower RMSD compared to the MMP-2 X-ray coordinates, with SC-74020 rendered in yellow ball and stick figures. (b) Docking result of SC74020 into the binding site of MMP-2 X-ray: the best scored pose and the NMR conformation are labeled as gray and yellow ball and stick figures, respectively.

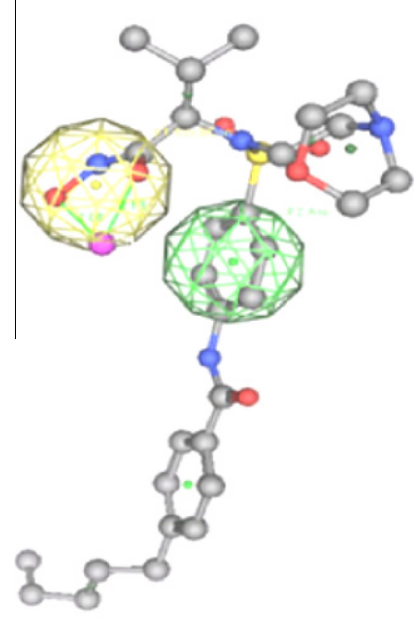

a

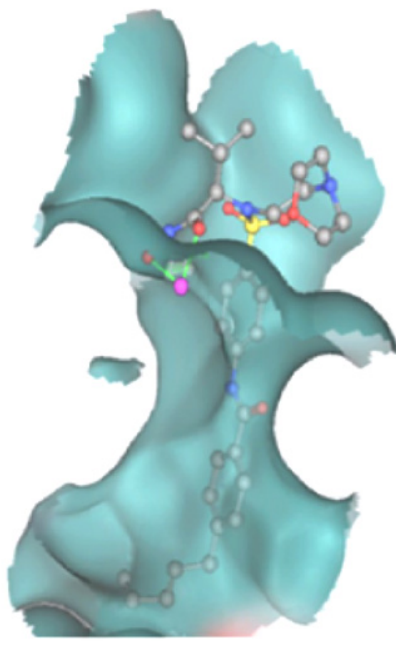

b
Figure 3. (a) Key pharmacophoric features defined on SC-74020 NMR conformation (pdb code: 1hov): F1 identified the zinc binding group, and the F2 corresponded to the $\mathrm{P}_{1}^{\prime}$ aromatic ring group, labeled as yellow and green spheres, respectively. (b) The excluded volume defined by the protein residues with at least one atom within $4.5 \AA$ from any atom of SC-74020.

deeper modifications, no further features were included to describe the long $\mathrm{P}_{1}^{\prime}$ group.

\subsection{D- and 3D-database generation}

About 2 million unique commercially available small molecules have been collected in a proprietary 2D small molecule database, namely MoDa (Molecular Database). By using MOE, drug-like filters were applied to remove non drug-like, toxic or reactive molecules. $^{22-24}$ Finally a number of around 600,000 unique structures were selected and for each molecule the 3D coordinates were derived. After energy minimization, for each 3D structure, a set of representative conformers was generated by molecular dynamic simulations. Low-energy conformations ( $\leqslant 5 \mathrm{kcal} / \mathrm{mol}$ from the global minimum) were included in the conformer database with a limit of 70 conformers per molecule, for the most flexible structures.

\subsection{Pharmacophore based virtual screening}

The derived 3D database was screened in MOE against the pharmacophore model. Hit compounds were ranked according to the score value defined by the RMSD of the aligned pharmacophoric points onto the pharmacophore model: no overlap on the excluded volume was permitted and, finally, about 200,000 molecules were identified. In order to select a more restricted number of compounds to be assayed against gelatinases, the selection was limited to a set of compounds bearing classical zinc binding groups (ZBG) such as carboxylic and hydroxamic acids. A molecular weight limit of 300 Da was imposed and a set of 150 compounds was obtained. Virtual hits were then visually inspected and selected following two criteria: synthetic feasibility and easiness to perform chemical modifications. Among the hit list, 15 compounds were selected, purchased, and assayed. The virtual screening flowchart is summarized in Figure 4, while the most representative compounds are depicted in Figure 5.

Among the screened compounds, the pyroglutamic acid derivative $(S)-\mathbf{1}^{\prime} \mathbf{b}$ showed an in vitro MMP-2 inhibitory activity in the micromolar range $\left(\mathrm{IC}_{50}=315 \mu \mathrm{M}\right)$, prompting us to consider it 


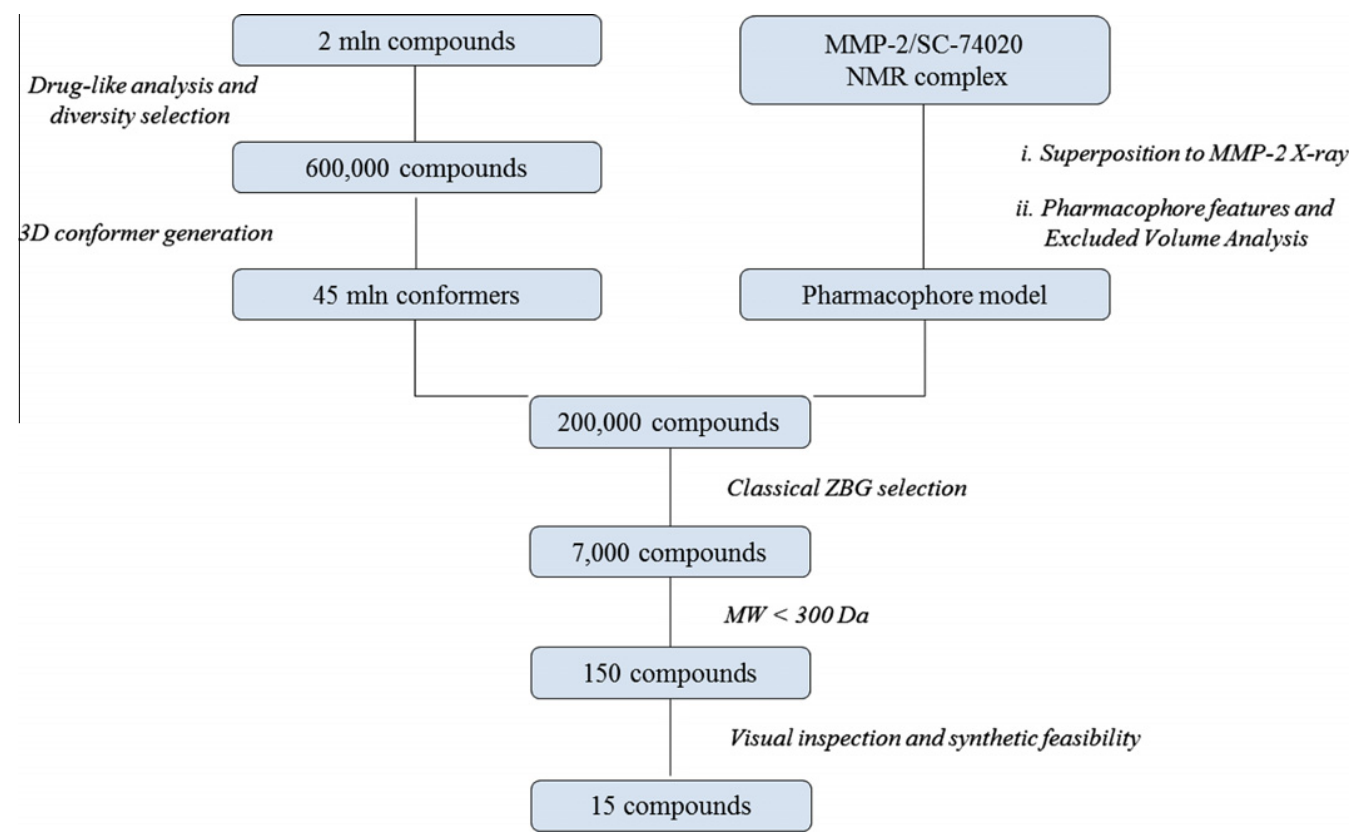

Figure 4. Virtual screening pharmacophore based flow-chart.

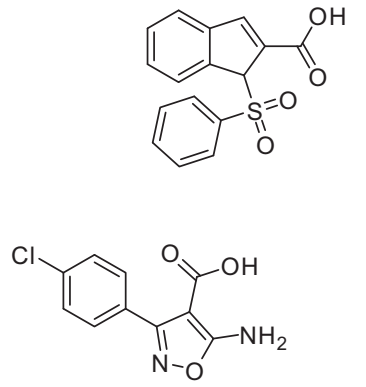<smiles>OCc1cnc(-c2ccc(Cl)cc2)s1</smiles><smiles>COc1ccc(-c2noc(C)c2C(=O)O)cc1</smiles><smiles>O=C(O)C1CCC(=O)N1Cc1ccccc1Cl</smiles><smiles>O=C(O)c1cccnc1Oc1ccccc1</smiles>

(S)-1'b<smiles>O=C(O)c1snnc1-c1ccccc1</smiles>

Figure 5. Selected hits from the in silico screening of MoDa database.

as a promising chemical scaffold for a new class of gelatinase inhibitors.

\subsection{Chemical modification on selected scaffold}

A first series of chemical modifications were performed on $(S)$ $\mathbf{1}^{\prime} \mathbf{b}$ template in order to investigate the influence on gelatinase inhibitory activity of (1) halogen position on the aromatic ring, (2) benzene ring replacement with a well-fitting $\mathrm{P}_{1}^{\prime}$ substituent (biphenyl moiety), (3) introduction of a non-carboxylic acid ZBG (hydroxamic acid or amide group) and (4) chirality. These compounds were synthesized according to Schemes 1 and 2 and biologically screened against MMP-2 and MMP-9 (Table 1).

The biological data confirmed the expected results in terms of best ZBG and $\mathrm{P}_{1}^{\prime}$ residues, while no significant effect of stereochemistry at $\mathrm{C} 5$ position was recorded. The in vitro screening led us to the identification of several hits and one of which, (S)-1a, was selected as the most versatile and promising hit, with a $\mathrm{IC}_{50}$ equal to 9 and $144 \mu \mathrm{M}$ on MMP-2 and MMP-9, respectively.

\subsection{Hit to lead}

In order to improve gelatinase inhibitor potency, different chemical modifications were performed on the $(S)$-1a pyroglutamate moiety, keeping the ZBG and $\mathrm{P}_{1}^{\prime}$ groups unchanged (Fig. 6) and evaluating chemical modifications on the five-membered ring and the methylene group. The pyroglutamate ring was replaced with commercially available proline (2a), thiazolidine (3a) and hydroxyproline (4a). Thiazolidinone derivative $\mathbf{5 a}$ was synthesized to investigate the influence of both the carbonyl group and the sulfur atom on the ring. Moreover, we synthesized the sulfonamide derivatives of pyroglutamate (6a), proline (7a), and thiazolidine (8a) since several literature data reported aryl-sulfonamide substituents to be the most favorable ones. ${ }^{25}$

All novel compounds were synthesized (Scheme 3-6) and tested against gelatinases (Table 2). SAR analysis suggested that the introduction of a polar group, such as a carbonyl moiety at $\mathrm{Y}$, maintaining a methylene group at $Z$ position, strongly increases the inhibitory potency (i.e., 1a vs $\mathbf{2 a}$; $5 \mathbf{a}$ vs $\mathbf{3 a}$ ). Nevertheless, when the methylene group in $\mathrm{Z}$ is replaced with the $\mathrm{SO}_{2}$ function, the influence of the carbonyl moiety in $\mathrm{Y}$ is negligible (i.e., 6a vs 7a). In contrast, the $\mathrm{SO}_{2}$ group in $\mathrm{Z}$ enhances the positive effect of the substitution in the $X$ position with a sulfur atom (compare compounds $\mathbf{2 a} / \mathbf{3 a}, \mathbf{1 a} / \mathbf{5 a}$ and $\mathbf{7 a} / \mathbf{8 a}$ ). We identified compound $\mathbf{8 a}$ as lead compound, with an $\mathrm{IC}_{50}$ value of $200 \mathrm{nM}$ and of $230 \mathrm{nM}$ towards MMP-2 and MMP-9, respectively. In order to get a more detailed representation of the recognition features, the compound was docked into the binding site of MMP-2 crystal structure. 


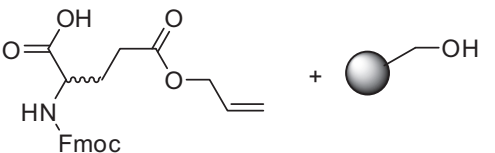

$11(\mathrm{R} / \mathrm{S})$

NovaSyn TG-OH

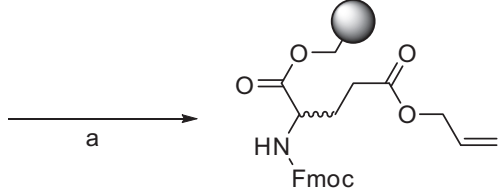

$12(\mathrm{R} / \mathrm{S})$

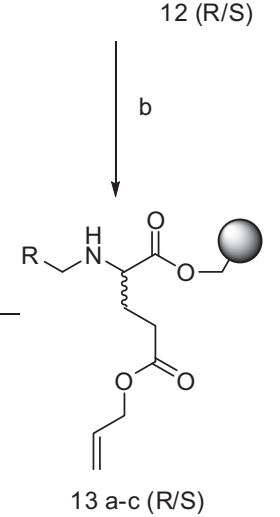

C

$13 \mathrm{a}-\mathrm{c}(\mathrm{R} / \mathrm{S})$

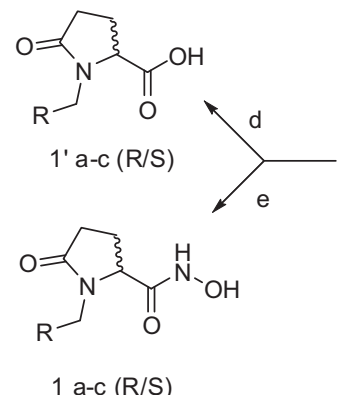<smiles>[R]CN1C(=O)CC[C@H]1C(=O)OCc1ccccc1</smiles>

14 a-c (R/S)

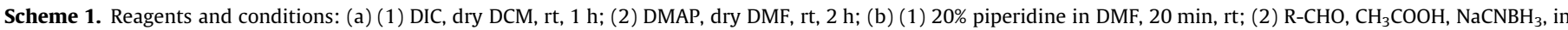
TMOF/MeOH, rt, 1 h; (c) (1) $\mathrm{PhSiH}_{3}, \mathrm{Pd}\left[\mathrm{P}(\mathrm{Ph})_{3}\right]_{4}$, dry DCM (2 5 min); (2) HATU, DIEA, dry DMF, rt, 3 h; (d) NaOH 0.5\%, rt, 1.5 h; (e) NH $\mathrm{NH}^{2} \mathrm{OH} \%$ wt in $\mathrm{H}_{2} \mathrm{O}, \mathrm{THF}, \mathrm{rt}, 5$ h.

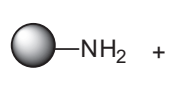<smiles>C=CCOC(=O)CCCC(NC=O)C(=O)O</smiles>

$11(\mathrm{R} / \mathrm{S})$

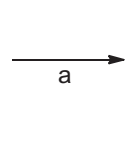

$15(\mathrm{R} / \mathrm{S})$

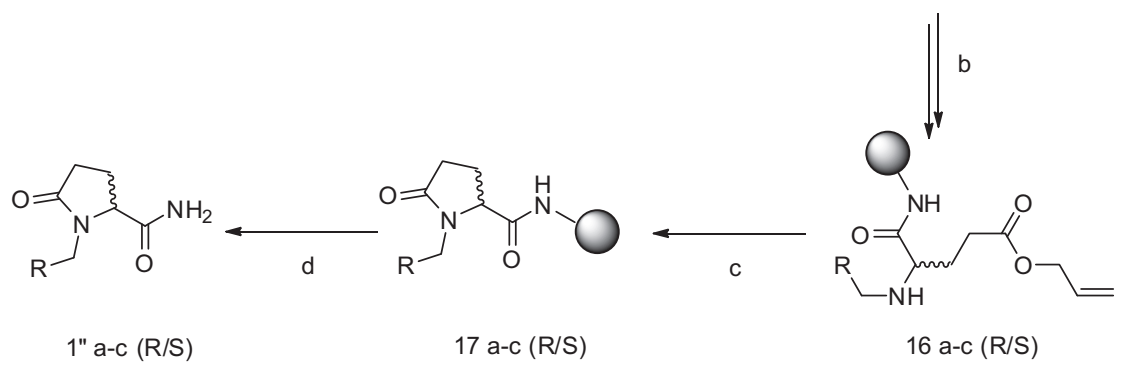

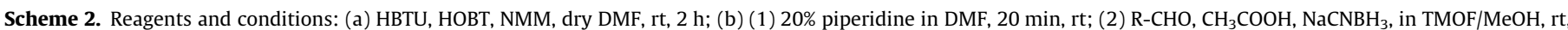
$1 \mathrm{~h}$; (c) (1) $\mathrm{PhSiH}_{3}, \mathrm{Pd}\left[\mathrm{P}(\mathrm{Ph})_{3}\right]_{4}$, dry DCM (2 × 5 min); (2) HATU, DIEA, dry DMF, rt, 3 h; (d) TFA/TIS (95:5), rt, 1 h.

The results revealed that compound 8a adopts the expected binding mode with $\mathrm{P}_{1}^{\prime}$ moiety involved in hydrophobic interactions with $S_{1}^{\prime}$ residues, giving high docking score in according with experimental data (data not shown).

\subsection{8a scaffold optimization}

From compound 8a further modifications were performed on $\mathrm{P}_{1}^{\prime}$ group. Several 8a analogues bearing different bulky groups in $\mathrm{R}$ position were synthesized, most of them being related to known and potent MMP inhibitors. Furthermore, the effects on the biological activity of the $-\mathrm{S}$ - substitution on the five-membered ring with sulfoxide and sulfone moiety were evaluated.

All the compounds were synthesized and tested against MMP-2 and MMP-9 (Table 3). According to the biological data, the substitution of the biphenyl moiety with more rigid groups, such as naphthalene or quinoline, dramatically decreases the inhibitor activity on both gelatinases (i.e., $\mathbf{8 h}$ and $\mathbf{8 i}$ ), while, as expected, a relevant 20-fold improvement occurs upon substitution of the biphenyl ring with a para-substituted diaryl ether (see compounds 8j, 8k, 81 in Table 3).

Subsequently, the accomplishment of a further improvement in inhibitory activity and a good degree of selectivity between the two gelatinases were achieved through substitution of $-\mathrm{S}-$ by $-\mathrm{S}(\mathrm{O})_{n}-$ (where $n=1$ or 2, see compound 9a and 10a in Table 3).

To underline the selectivity profiles over other MMPs, the most promising compounds were tested against a broader panel of MMPs (Table 4).

Compounds 8k and $\mathbf{8 1}$ exhibited a relevant rate of discrimination with respect to MMP-1 and MMP-3. Moreover, compounds 9a and 10a showed a significant MMP-2 selectivity even over MMP-9. Unfortunately, more the activity increases, more the selectivity fades out. In addition, data collected for compound 10k (Table 4) show that when gelatinase activity is in the low nanomo- 
Table 1

Gelatinase A and B inhibitory activity of $(R)$ - and $(S)-\mathbf{1}$ derivatives

\begin{tabular}{|c|c|c|c|c|c|c|c|}
\hline \multirow[t]{2}{*}{$\mathbf{R}$} & \multirow[t]{2}{*}{$\mathbf{X}$} & \multirow[t]{2}{*}{ Cpd } & \multicolumn{2}{|c|}{$\mathrm{IC}_{50}(\mathrm{M})^{\mathrm{a}}$} & \multirow[t]{2}{*}{ Cpd } & \multicolumn{2}{|c|}{$\mathrm{IC}_{50}(\mathrm{M})^{\mathrm{a}}$} \\
\hline & & & MMP-2 $^{\mathrm{b}}$ & MMP-9 ${ }^{\mathrm{b}}$ & & MMP-2 $^{\mathrm{b}}$ & MMP-9 \\
\hline & $\mathrm{CONHOH}$ & $(R)-\mathbf{1 a}$ & $3 \pm 0.3$ & $30 \pm 3$ & $(S)-\mathbf{1 a}$ & $9 \pm 1$ & $144 \pm 10$ \\
\hline & $\mathrm{COOH}$ & $(R)-\mathbf{1}^{\prime} \mathbf{a}$ & 290 & ND & $(S)-\mathbf{1}^{\prime} \mathbf{a}$ & 340 & ND \\
\hline & $\mathrm{CONH}_{2}$ & $(R)-\mathbf{1}^{\prime \prime} \mathbf{a}$ & $>500$ & ND & $(S)-\mathbf{1}^{\prime \prime} \mathbf{a}$ & $>500$ & ND \\
\hline & $\mathrm{CONHOH}$ & $(R)-\mathbf{1 b}$ & $>500$ & $>500$ & $(S)-\mathbf{1 b}$ & $>500$ & ND \\
\hline & $\mathrm{COOH}$ & $(R)-\mathbf{1}^{\prime} \mathbf{b}$ & $>500$ & ND & $(S)-\mathbf{1}^{\prime} \mathbf{b}$ & 315 & ND \\
\hline & $\mathrm{CONH}_{2}$ & $(R)-\mathbf{1}^{\prime \prime} \mathbf{b}$ & $>500$ & ND & $(S)-\mathbf{1}^{\prime \prime} \mathbf{b}$ & $>500$ & ND \\
\hline & $\mathrm{CONHOH}$ & $(R)-\mathbf{1 c}$ & $400 \pm 20$ & 430 & $(S)-\mathbf{1 c}$ & $>500$ & ND \\
\hline & $\mathrm{COOH}$ & $(R)-\mathbf{1}^{\prime} \mathbf{c}$ & $>500$ & ND & $(S)-\mathbf{1}^{\prime} \mathbf{c}$ & 383 & ND \\
\hline & $\mathrm{CONH}_{2}$ & $(R)-\mathbf{1}^{\prime \prime} \mathbf{c}$ & $>500$ & ND & $(S)-\mathbf{1}^{\prime \prime} \mathbf{c}$ & $>500$ & ND \\
\hline
\end{tabular}

a ND: not determined.

b MMP2: full length; MMP9: catalytic domain.

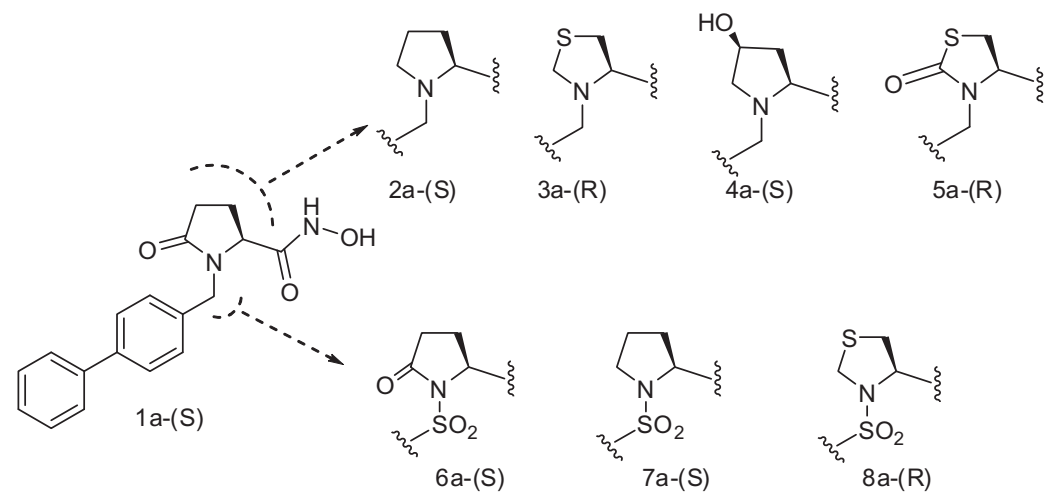

Figure 6. (S)-1a scaffold modifications.

lar range, high activity is recorded also towards other MMP members.

\subsection{In silico investigation of MMP-2 selectivity over MMP-9}

To investigate the different activity of $\mathbf{9 a}$ and $\mathbf{1 0 a}$ towards the two gelatinases, docking analysis on MMP-9 and MMP-2 binding sites was performed (see Section 5 for details). The comparison of the best scored solutions of both molecules highlighted a different binding mode in the two protein binding sites. For instance, visual inspection of 10a binding mode (Fig. 7) revealed that one oxygen atom of the sulfonamide group can form an hydrogen bond with the NH group of MMP-9 Gln402 side-chain while in MMP-2 the hydroxamic $\mathrm{NH}$ group is involved in a hydrogen bond with the backbone of Ala165. The most remarkable difference in the binding modes of the two inhibitors relies on a significant change of overall shapes of the two heterocyclic rings in the two gelatinases. In MMP-2 binding site, one oxygen of the endocyclic $\mathrm{SO}_{2} / \mathrm{SO}$ is involved in an hydrogen bond with the $\mathrm{NH}$ group of Ala164 backbone, while in MMP-9 the same group does not give further interactions, leading to a lower docking score (10a: 82.01 and 69.70, respectively). The lack of this additional favorable interaction is probably due to the presence of a larger $S_{1}^{\prime}$ pocket that forces the molecules to plunge in deeply.

\section{Solid phase synthesis}

A versatile solid phase strategy for the synthesis of scaffolds 1-8 was developed.

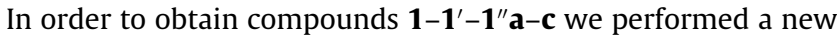
synthetic solid phase approach using either a NovaSyn Tentagel resin or a Rink amide resin depending on whether the final cleavage should release a carboxylic/hydroxamic or an amidic moiety (Scheme 1 and 2). Both enantiomers of Fmoc-protected amino acid $\mathbf{1 1}$ were commercially available in pure enantiomeric form. Attachment to the resin followed by deprotection of the Fmoc group and subsequent reductive amination with appropriate alkylating reagents provided N-alkylated compounds 13-16a-c. Removal of the protective group easily allowed condensation of the pyroglutamic ring to obtain 14-17a-c. Final cleavage from the resin gave compounds 1-1'-1"a-c with good purity degree (>90\% by HPLCMS). 


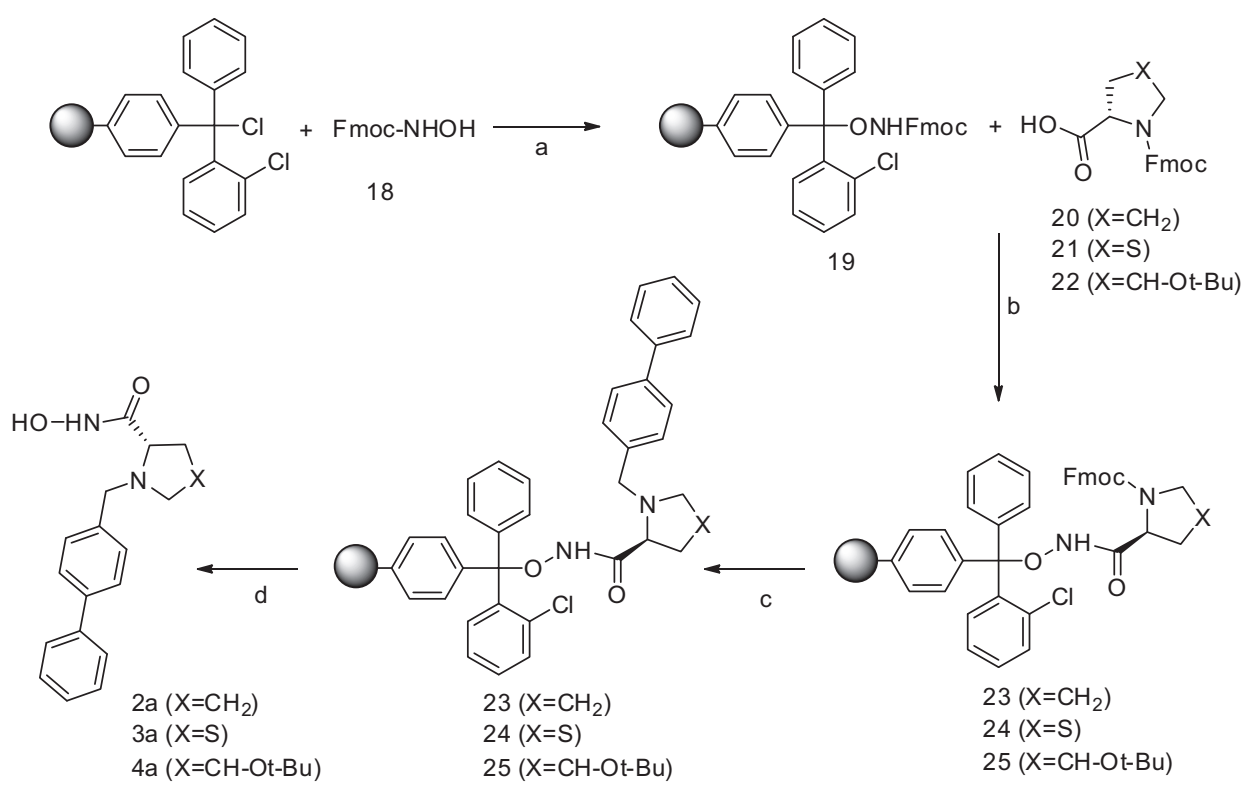

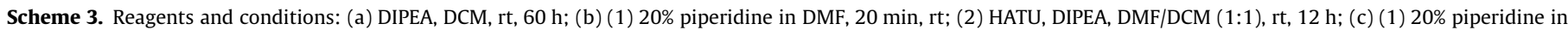
DMF, 20 min, rt; (2) 4'-(Ph)-PhCHO, $\mathrm{CH}_{3} \mathrm{COOH}, \mathrm{NaCNBH}_{3}$, in TMOF/MeOH, rt, $1 \mathrm{~h}$; (d) AcOH/TFE/DCM (1:1:8), rt, 1 h.

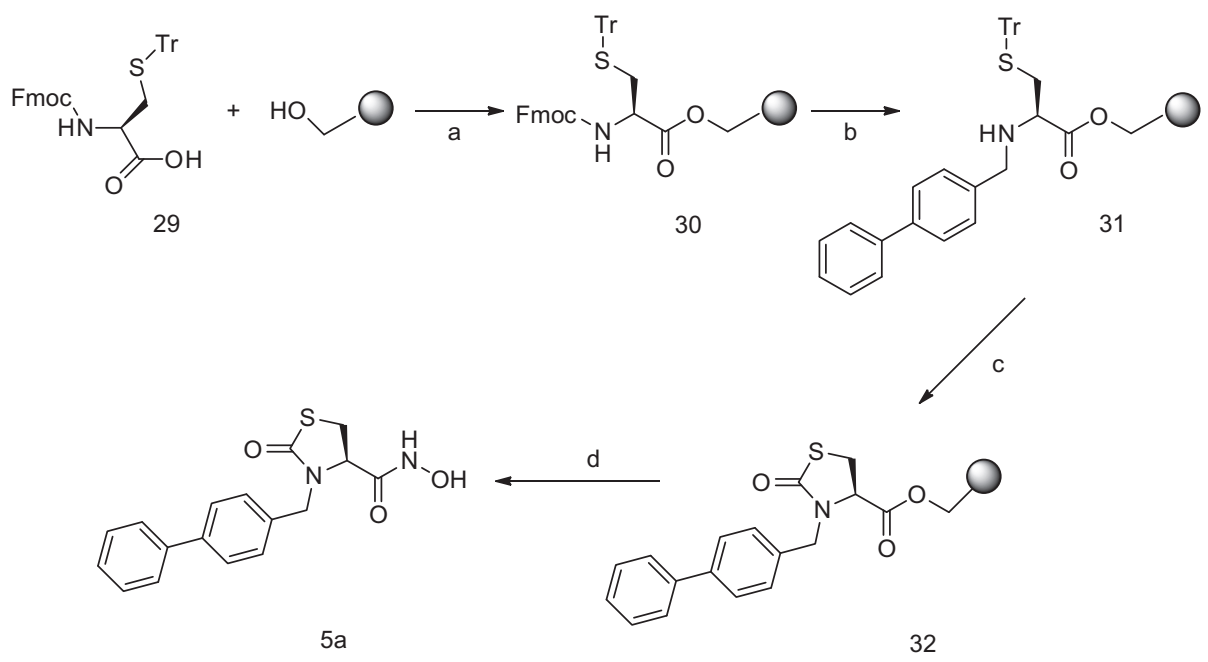

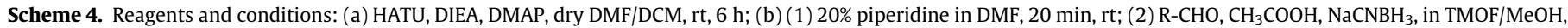
rt, 1 h; (c) (1) TFA/TIS/DCM (10:5:85); (2) 10\% $\mathrm{Et}_{3} \mathrm{~N}$ in DMF, 5 min, rt; (3) CDI, dry DCM, rt, 6 h; (d) $\mathrm{NH}_{2} \mathrm{OH} \mathrm{50 \%} \mathrm{wt} \mathrm{in} \mathrm{H}_{2} \mathrm{O}$, THF, rt, 5 h.

To obtain compounds $\mathbf{2 a}$, 3a and $\mathbf{4 a}$ Fmoc protected hydroxylamine was tethered to 2-chloro-chlorotrytil resin, which proved to be suitable to ensure the final release of hydroxamic derivatives (Scheme 3). After removal of the Fmoc group, coupling of compound 19 with Fmoc-protected proline/thioproline/hydroxyproline-carboxylic acids 20-22 gave compounds 23-25. Fmoc group was then cleaved and subsequent reductive amination with p-phenylbenzaldehyde and cleavage from the resin released $\mathbf{2 a}, \mathbf{3 a}$ and $\mathbf{4 a}$ in good yields.

An innovative strategy was developed to obtain the oxothiazolidine hydroxamate derivative $\mathbf{5 a}$ (Scheme 4). The compound was conveniently synthesized starting from Fmoc protected $(R)$-2-amino3-(tritylthio)propanoic acid 29. The substrate was anchored on NovaSyn Tentagel resin and after Fmoc cleavage reductive amination with $p$-phenylbenzaldehyde was performed. Compound $\mathbf{3 1}$ was then deprotected, cyclized, and cleaved from the resin to give compound 5a.
An original pattern was then envisaged to synthesize compound 6, which maintained the same $\mathrm{ZBG}$ and $\mathrm{P}_{1}^{\prime}$ substituent as $\mathbf{5 a}$, changing the thiazolidinone ring into a pyrrolidonone (Scheme 5). Carboxylic acid $(S)-\mathbf{1 1}$ was converted to hydroxamic acid $(S)-\mathbf{3 3}$ and anchored on 2-chloro-chlorotrytil resin to obtain $(S)$-34. Then, Fmoc deprotection followed by sulfonamide synthesis gave $(S)$ 35. Ring closing reaction occurred using the same conditions applied to synthesize derivatives $\mathbf{1 3}$ and $\mathbf{1 6}$ after acid deprotection (Scheme 1 and 2). Final cleavage from the resin using TFA produced 6 with high purity.

Compounds 7a, 8a, 8h-1, 9a, 10a, 10k were obtained only from two building blocks $\mathbf{2 0}$ and $\mathbf{2 1}$ (Scheme 6). NovaSyn Tentagel resin was chosen to tether the two acids. After Fmoc cleavage the amino group was reacted with several sulfonyl chlorides to obtain sulfonamides 39a and 40a, h-1.

Compounds 39a and $\mathbf{4 0 h - 1}$ were immediately released from the resin to give $\mathbf{7 a}$ and $\mathbf{8 h}-\mathbf{l}$, while $\mathbf{4 0 a}$ was split into two different 


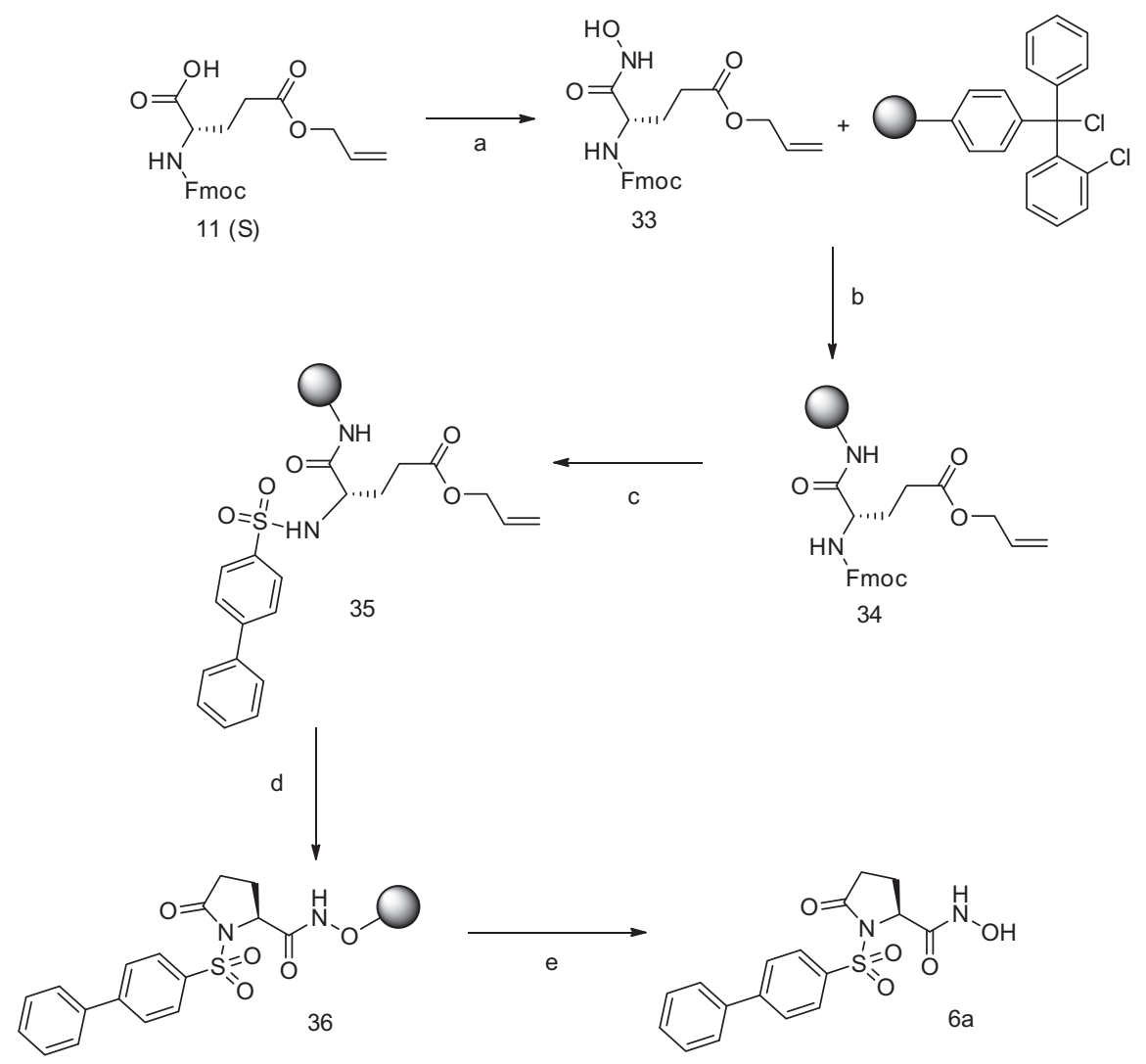

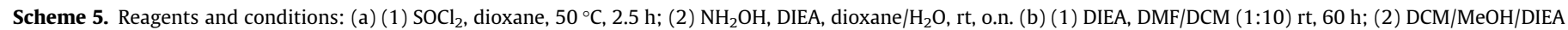

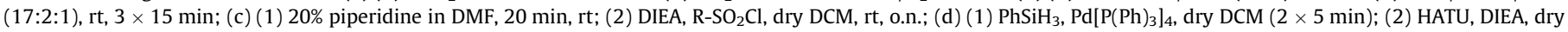
DMF, rt, 3 h; (e) TFA 5\%, DCM, rt, 2 h.

batches. The first batch was used to give 8a, the second one was oxidized with MCPBA, so to introduce a sulfone moiety on the ring to give 41a. Compound 41a was again split in two in order to obtain 9a and perform the oxidation of sulfone to sulfoxide to finally release $\mathbf{1 0 a}$.

\section{Conclusion}

In conclusion, a pharmacophore based virtual screening of our in-house database and further chemical optimization led us to design novel gelatinase inhibitors. The compounds were synthesized developing and applying a solid phase approach. Docking simulations were performed to study the possible motifs of selectivity between MMP-2 and MMP-9. Notably, a very interesting selectivity was observed for some compounds with good in silico drug-likeness profile. In particular the 4-thiazolydinyl- $N$-hydroxycarboxyamide derivatives 9a and 10a showed a MMP-2 inhibitory activity in the low nanomolar range and a good selectivity over the MMPs analysed in this study. The achieved results represent a good starting point for future research activities, directed toward further medicinal chemistry optimizations.

\section{Experimental section}

\subsection{Molecular modeling}

\subsubsection{MoDa-2D database}

MoDa is a web-based application developed using the Perl programming language, containing about 2 millions distinct molecules from about 9 millions commercially available compounds. MoDa uses MySQL as Relational Database management System and Apache as web server.

\subsubsection{MoDa-3D database}

By using MOE, the compounds were selected from the MoDa-2D database according to the drug-like criteria, by property descriptor calculation, which include: number of violations of the Lipinsky's rule of five and other drug-like filters such as number of rings, number of halogens and undesirable reactive groups. A subset of about 600,000 compounds were selected and used to generate a database of conformers. The conformational analysis search was carried out via molecular dynamic (MD) as implemented in the MOE software package. For each compound, an MD run of 1 ns was performed using the NVT ensemble with $T=300 \mathrm{~K}$, time step of 0.002 ps using MMFF94 force field and the Born solvation model. A total of 1000 conformations were collected for each MD run and they were energy-minimized requiring a RMSD of the gradient less than $0.05 \mathrm{kcal} / \mathrm{mol}$.

\subsubsection{Pharmacophore design}

MOE Pharmacophore Applications module has been used to design pharmacophore hypotheses and to perform database screening. The $\mathrm{PCH}$ pharmacophore scheme included the following atomic tags: H-Bond Acceptor, H-Bond Donor, Cation, Anion, Aromatic ring center, Hydrophobic Region, Metal Ligator, Volume Constraint. In detail, by using SC-74020 ligand coordinates as reference template, the first pharmacophoric point was fixed on hydroxamic group setting a tolerance radius of 1.8 Å to include one or both oxygen atoms of alternative other ZBGs (e.g. carboxylic acids, hydroxamic acids, phosphates). The second pharmacophoric point was defined on the $\mathrm{P}_{1}^{\prime}$ phenyl group, with a tolerance radius comparable with the size of an aromatic ring $(1.8 \AA)$. Finally, the overall shape of the protein around the catalytic site and the $S_{1}^{\prime}$ pocket was modeled considering the excluded volume defined by the protein residues with at least one atom within 4.5 A from any atom 

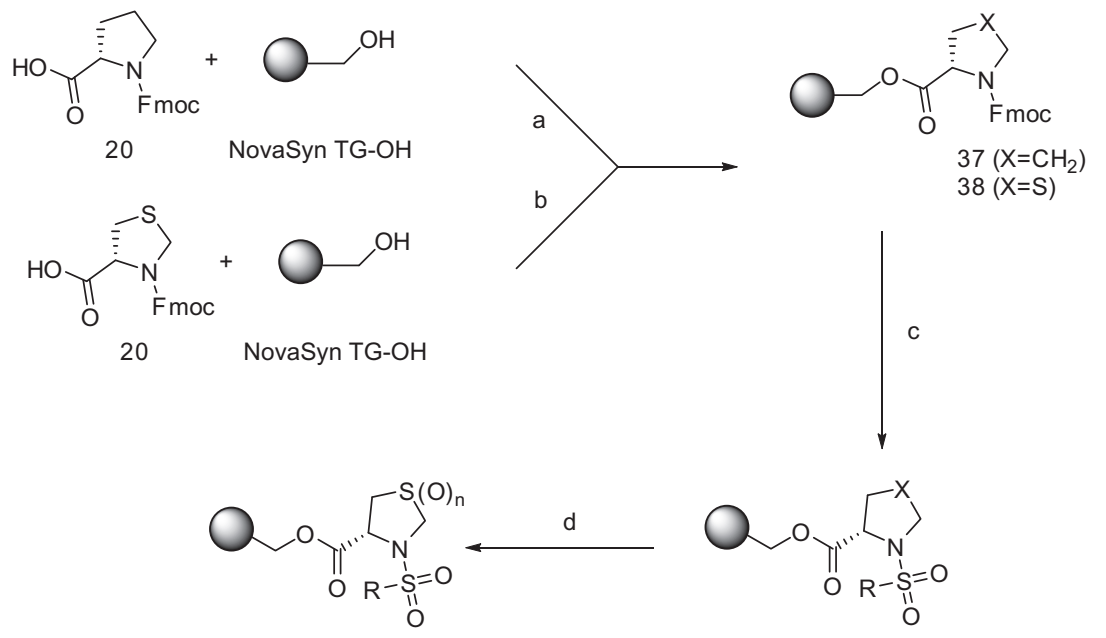

$e\left(\begin{array}{l}41 a(n=1) \\ 42 a(n=2)\end{array}\right.$

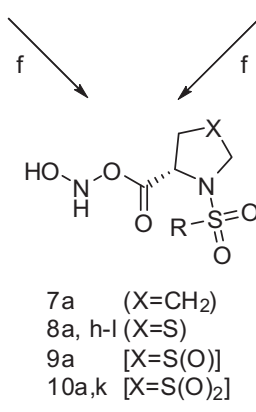

39 a $\left(\mathrm{X}=\mathrm{CH}_{2}\right)$

40 a, h-I (X=S)

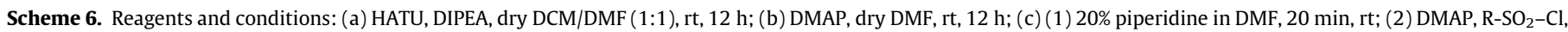
THF/DCM (2:1) rt, 12 h; (d) MCPBA, dry DCM, rt, 27 h; (e) MCPBA, dry DCM, rt, 27 h; (f) $\mathrm{NH}_{2} \mathrm{OH} 50 \%$ wt in $\mathrm{H}_{2} \mathrm{O}$, THF, rt, 5 h.

Table 2

Gelatinase A and B inhibitory activity of 1-8a compounds

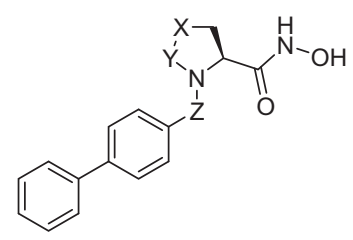

\begin{tabular}{llllll}
\hline & & & & \multicolumn{2}{c}{$\mathrm{IC}_{50}(\mu \mathrm{M})$} \\
\cline { 5 - 6 } Compd & $\mathrm{X}$ & $\mathrm{Y}$ & $\mathrm{Z}$ & $\mathrm{MMP2wh}^{\mathrm{a}}$ & MMP9cd $^{\mathrm{b}}$ \\
\hline $\mathbf{1 a}$ & $\mathrm{CH}_{2}$ & $\mathrm{C}(\mathrm{O})$ & $\mathrm{CH}_{2}$ & $9 \pm 1$ & $144 \pm 10$ \\
$\mathbf{2 a}$ & $\mathrm{CH}_{2}$ & $\mathrm{CH}_{2}$ & $\mathrm{CH}_{2}$ & $>500$ & $\mathrm{ND}$ \\
$\mathbf{3 a}$ & $\mathrm{S}$ & $\mathrm{CH}_{2}$ & $\mathrm{CH}_{2}$ & $330 \pm 15$ & $\mathrm{ND}$ \\
$\mathbf{4 a}$ & $\mathrm{CH}(\mathrm{OH})$ & $\mathrm{CH}_{2}$ & $\mathrm{CH}_{2}$ & $>500$ & $\mathrm{ND}$ \\
$\mathbf{5 a}$ & $\mathrm{S}$ & $\mathrm{C}(\mathrm{O})$ & $\mathrm{CH}_{2}$ & $6.80 \pm 1$ & $47 \pm 8$ \\
$\mathbf{6 a}$ & $\mathrm{CH}$ & $\mathrm{C}(\mathrm{O})$ & $\mathrm{SO}_{2}$ & $1.7 \pm 0.5$ & $1.9 \pm 0.1$ \\
$\mathbf{7 a}$ & $\mathrm{CH}$ & $\mathrm{CH}_{2}$ & $\mathrm{SO}_{2}$ & $4 \pm 1$ & $76 \pm 4$ \\
$\mathbf{8 a}$ & $\mathrm{S}$ & $\mathrm{CH}_{2}$ & $\mathrm{SO}_{2}$ & $0.20 \pm 0.01$ & $0.23 \pm 0.05$ \\
\hline
\end{tabular}

a MMP2wh: MMP2 full length.

b MMP9: full length; MMP9: catalytic domain.

of SC-74020. Around 200 atom points were used to describe the excluded volume in such a manner that also larger inhibitors should satisfy the same query (Fig. 3b).

\subsubsection{Docking simulations}

In the present study, the 3D coordinates of MMP-2 and MMP-9 (pdb codes: 1qib and 2ow1, respectively) were retrieved from the PDB. Protein preparation was performed in MOE: the two proteins were aligned, the water molecules, cofactors and (MMP-9) cocrystallized ligand were removed; by using Protonate 3D tool, the hydrogen atoms were added, fixing the correct protonation of protein residues. The inhibitors described in this work were built from the MOE fragment library and minimized by setting MMFF94 force field.

Docking simulations were performed using the GoLD program (Cambridge Crystallographic Data Centre, Cambridge, UK) by setting the GoldScore (GS) fitness functions to quantify the interaction energy of ligand-protein complexes. The fitness function parameters were taken from the GoLD parameter file. The binding cavities contained the protein residues in a sphere of a $12 \AA$ radius centred on the SC-74020 aromatic carbon C18. Zinc trigonal/bipyramidal coordination geometry was imposed. For each compounds, 10 poses were generated into the binding site of MMP-2 and MMP9 , respectively. The binding mode inspections were carried out by Hermes Viewer implemented in GoLD software.

\subsubsection{Additional softwares}

Visual inspections of docking and pharmacophore analysis were performed with PyMOL. ${ }^{26}$ In addition MOE, Babel, CDK and JOELib were used as chemoinformatic tools for SMARTS search, conversion, and other routine tasks.

\subsection{Chemistry}

Reagents and solvents were obtained from commercial suppliers and used without further purification. Thin layer chromatography (TLC) analytical separations were conducted with E. Merck Silica Gel F-254 plates of $0.25 \mathrm{~mm}$ thickness and were visualized with UV light ( $254 \mathrm{~nm}$ ) or $\mathrm{I}_{2}$. Flash chromatography was performed 
Table 3

MMP-2 e MMP-9 screening results of 8a analogues<smiles>[R]S(=O)(=O)N1CS(=O)(=O)C[C@H]1C(=O)NO</smiles>

Compd

using E. Merck silica gel. ${ }^{1} \mathrm{H}$ nuclear magnetic resonance (NMR) spectra were recorded in the specified deuterated solvents on a Bruker Avance 300 spectrometer operating at $300 \mathrm{MHz}$. Chemical shifts are reported in parts per million $(\delta)$ from the tetramethylsilane resonance in the indicated solvent (TMS: $0.0 \mathrm{ppm}$ ). Compounds purities and mass spectra were determined by an LC/MS platform (Gilson/ThermoFinnigan) using the positive electrospray ionization technique (+ES) with a mobile phase of acetonitrile/ water with $0.1 \%$ TFA.
Elementary analyses were performed on a Perkin-Elmer 2400 Series II Elemental Analyser and a microbalance AD-4 autobalance Perkin-Elmer.

Optical rotations were determined at $25{ }^{\circ} \mathrm{C}$ on a Perkin-Elmer 341 polarimeter (concentrations are reported in units of grams per $100 \mathrm{~mL}$ ).

\subsubsection{General methods for solid phase synthesis}

Solvents were distilled for resin reactions. Unless otherwise stated reactions were performed in $8 \mathrm{~mL}$ polypropylene cartridges with $70 \mathrm{~mm}$ PE frits. Cartridges and stopcocks were obtained from Applied Separations. All Fmoc amino acids, coupling reagents, and resins were purchased from Novabiochem, and other chemicals were from Aldrich.

\subsubsection{General procedures for coupling of Fmoc-(D/L)-Glu-(OAll)- OH to NovaSynTGOH \\ Example: Synthesis of $(R)-\mathbf{1 2}$.}

$N, N^{\prime}$-Diisopropylcarbodiimide (DIC) $(300 \mu \mathrm{l}, 1.9 \mathrm{mmol})$ was added to a solution of Fmoc-D-Glu-(OAll)-OH $(R)-\mathbf{1 1}(1.55 \mathrm{~g}, 3.8 \mathrm{mmol})$ in $10 \mathrm{ml}$ dry DCM at $0{ }^{\circ} \mathrm{C}$. After stirring at room temperature for $1 \mathrm{~h}$, DCM was evaporated, $3 \mathrm{ml}$ of DMF were added and the solution was dropped into the cartridge in which hydroxyl group functionalized resin (NovaSynTGOH) $(1.26 \mathrm{~g}, 0.38 \mathrm{mmol})$ was pre-swollen in DCM. 4-Dimethylaminopyridine (DMAP) ( $5 \mathrm{mg}, 0.04 \mathrm{mmol}$ ) in $0.3 \mathrm{ml}$ dry DMF was introduced and the cartridge was gently rocked for $2 \mathrm{~h}$ at room temperature.

After filtration the resin was rinsed with DMF $(3 \times 5 \mathrm{ml}), \mathrm{DCM}$ $(3 \times 5 \mathrm{ml})$ and TBME $(3 \times 5 \mathrm{ml})$ and finally dried in vacuo.

The efficiency of loading (loading yield: $81 \%$ ) was determined on $5.9 \mathrm{mg}$ of resin by Fmoc removal analysis (treatment of the resin with piperidine $20 \%$ in DMF) and absorbance measurement at $301 \mathrm{~nm}$ (UV-vis Spectrophotometer Shimadzu).

\subsubsection{General procedures for Fmoc deprotection and reductive amination of polymer bound $0-A l l-(\mathrm{D} / \mathrm{L})$ glutamate}

Example: Synthesis of $(R)-\mathbf{1 3 a}$.

After Fmoc deprotection with $20 \%$ piperidine in DMF for $20 \min (\times 2),(R)-12(0.08 \mathrm{mmol})$ was washed $(2 \times \mathrm{DMF}, 2 \times \mathrm{DCM})$ and swollen in DCM, then biphenyl-4-carboxaldehyde $(120 \mathrm{mg}$, $0.66 \mathrm{mmol}$ ) in $0.8 \mathrm{ml}$ trimethyl orthoformate (TMOF) was added dropwise. Subsequently methanol $(\mathrm{MeOH})(200 \mu \mathrm{l})$, acetic acid $(38 \mu \mathrm{l}, 0.66 \mathrm{mmol})$ and $\mathrm{NaCNBH}_{3}(124 \mathrm{mg}, 1.97 \mathrm{mmol})$ in $\mathrm{MeOH}$ $(400 \mu \mathrm{l})$ were respectively introduced into the reaction mixture. After shaking for $1 \mathrm{~h}$ at room temperature, the resin was filtered and washed with $\mathrm{MeOH}(\times 3), \mathrm{DMF}(\times 3), \mathrm{DCM}(\times 3)$ and TBME $(\times 3)$.

\subsubsection{General procedures for allyl deprotection and cyclization Example: Synthesis of $(R)-\mathbf{1 4 a}$.}

$\mathrm{PhSiH}_{3}(500 \mu \mathrm{l}, 4.1 \mathrm{mmol})$ and $\mathrm{Pd}\left[\mathrm{P}(\mathrm{Ph})_{3}\right]_{4}(95 \mathrm{mg}, 0.08 \mathrm{mmol})$ in $2 \mathrm{ml}$ dry DCM were added to $0.08 \mathrm{mmol}$ of $(R)$-13a pre-swollen in DCM.

Table 4

Biological data collected for compounds 8a analogues

\begin{tabular}{|c|c|c|c|c|c|c|c|}
\hline \multicolumn{8}{|c|}{$\mathrm{IC}_{50}(\mathrm{nM})$} \\
\hline Compd & MMP2 & MMP9 & MMP1cd & MMP3cd & MMP8cd & MMP12cd & MMP14cd \\
\hline $8 j$ & $9 \pm 1$ & $2 \pm 0.3$ & ND & ND & ND & ND & ND \\
\hline 8k & $13 \pm 5$ & $16 \pm 9$ & $1000 \pm 50$ & $160 \pm 30$ & ND & ND & ND \\
\hline 81 & $10 \pm 2$ & $5 \pm 0.5$ & $>50,000$ & $700 \pm 100$ & ND & ND & ND \\
\hline $9 a$ & $9 \pm 3$ & $600 \pm 100$ & $4000 \pm 500$ & $2000 \pm 300$ & $400 \pm 100$ & $2500 \pm 500$ & $160 \pm 20$ \\
\hline $10 a$ & $53 \pm 16$ & $480 \pm 80$ & $2500 \pm 100$ & $4000 \pm 100$ & $100 \pm 40$ & $500 \pm 10$ & $3800 \pm 500$ \\
\hline $10 k$ & $0.8 \pm 0.1$ & $0.5 \pm 0.07$ & ND & ND & $4 \pm 1$ & $19 \pm 6$ & $5 \pm 0.5$ \\
\hline
\end{tabular}




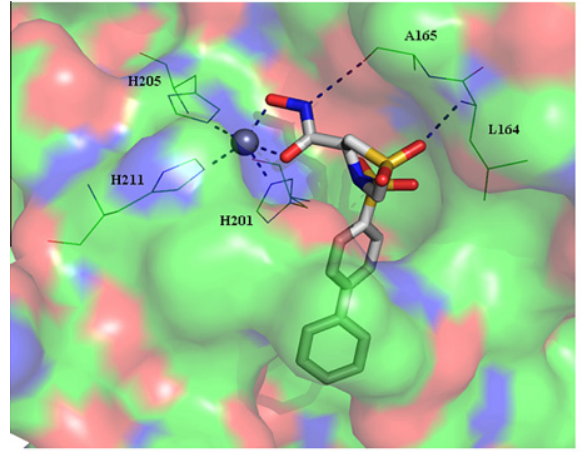

a

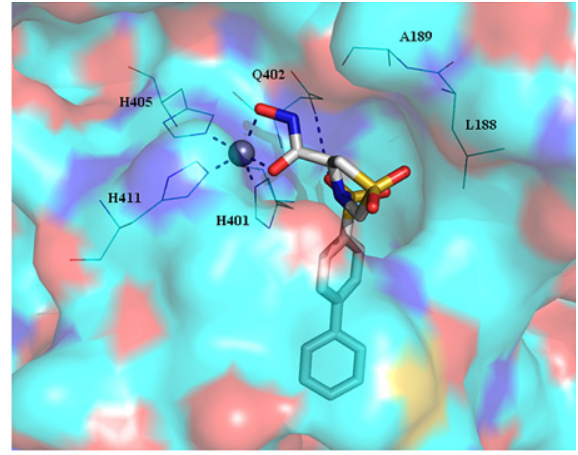

b

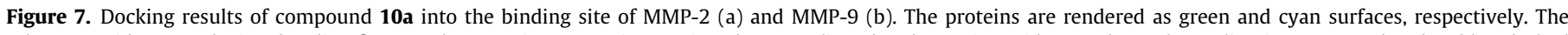

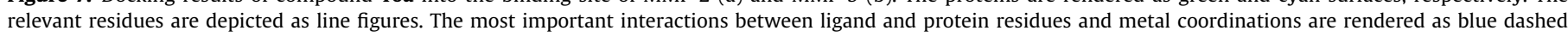
lines. Zinc ion is rendered as gray sphere.

After repeating the treatment twice $(2 \times 5 \mathrm{~min})$ the resin was filtered, rinsed first with DCM, and later with a solution of DIEA $(0.5 \%)$ and $\mathrm{NaEt}_{2} \mathrm{NCS}_{2}(0.5 \%)$ in DMF, and again with DMF, DCM and DMF.

DIEA $(17 \mu \mathrm{l}, 0.01 \mathrm{mmol})$ and a solution of HATU (2-(1H-9azabenzotriazole-1-yl)-1,1,3,3-tetramethyluronium hexafluorophosphate) (38 $\mathrm{mg}, 0.01 \mathrm{mmol}$ ) previously dissolved in $0.7 \mathrm{ml}$ of dry DMF were introduced into the cartridge; the cyclization proceeded for $3 \mathrm{~h}$ at room temperature. The resin was filtered and rinsed with $\operatorname{DMF}(\times 3), \mathrm{MeOH}(\times 3), \mathrm{DCM}(\times 3)$ and TBME $(\times 3)$.

\subsubsection{General procedures for the cleavage of hydroxamate derivatives 1}

Example: (R)-1-(4-phenylbenzyl)- $N$-hydroxy-5-oxopyrrolidine2-carboxamide $[(R)-\mathbf{1 a}]$.

Functionalized resin derivative $(R)-\mathbf{1 4 a}(0.04 \mathrm{mmol})$ was swollen in THF $(1.8 \mathrm{ml})$ and cleaved from the solid support by treatment with $50 \% \mathrm{NH}_{2} \mathrm{OH}$ in $\mathrm{H}_{2} \mathrm{O}(300 \mu \mathrm{l}, 5.6 \mathrm{mmol})$. After rocking for $5 \mathrm{~h}$ at room temperature, the resin was filtered and the filtrate was evaporated to dryness.

The crude product was further purified by semi-preparative RPHPLC (C18, Nucleosil $300 \mathrm{~mm} \times 25 \mathrm{~mm}, 3 \mathrm{ml} / \mathrm{min}$, detection at $230 \mathrm{~nm}$, eluent A: Water/TFA: 99.92:0.08, eluent B: acetonitrile/ TFA: 99.92:0.08; gradient B from $20 \%$ to $80 \%$ in 14 min, from $80 \%$ to $98 \%$ in $3 \mathrm{~min}$ ) to afford (R)-1a.

Amorphous solid- ${ }^{1} \mathrm{H}$ NMR $\left(300 \mathrm{MHz}\right.$, DMSO- $\left.d_{6}\right): \delta 1.82-1.90$ $(\mathrm{m}, 1 \mathrm{H}), 2.1-2.2(\mathrm{~m}, 1 \mathrm{H}), 2.29-2.45(\mathrm{~m}, 2 \mathrm{H}), 3.65(\mathrm{~d}, 1 \mathrm{H}$, $J=14.7 \mathrm{~Hz}$ ), 3.82 (dd, $1 \mathrm{H}, J=8.8,3.9 \mathrm{~Hz}), 4.90$ (d, $1 \mathrm{H}, J=14.7 \mathrm{~Hz}$ ), $7.27(\mathrm{~d}, 2 \mathrm{H}, J=7.8 \mathrm{~Hz}), 7.36(\mathrm{t}, 1 \mathrm{H}, J=14.7,7.8 \mathrm{~Hz}), 7.46$ (dd as t, $2 \mathrm{H}, J=15.6,7.8 \mathrm{~Hz}), 7.63(\mathrm{~d}, 2 \mathrm{H}, J=7.8 \mathrm{~Hz}), 7.65(\mathrm{~d}, 2 \mathrm{H}$, $J=5.9 \mathrm{~Hz}$ ), 9.08 (br s, 1H), 10.79 (br s, 1H). LC-MS (ESI) $\left(\mathrm{H}_{2} \mathrm{O} /\right.$ $\mathrm{CH}_{3} \mathrm{CN}, 1 \%$ TFA) $m / z(\%): 311.3\left(\mathrm{MH}^{+}, 100\right), \mathrm{C}_{18} \mathrm{H}_{18} \mathrm{~N}_{2} \mathrm{O}_{3}$ : 310.3. Specific optical rotation $[\alpha]_{\mathrm{D}}^{25}-51\left(c 0.02, \mathrm{CH}_{3} \mathrm{OH}\right)$. Anal. Calcd for $\mathrm{C}_{18} \mathrm{H}_{18} \mathrm{~N}_{2} \mathrm{O}_{3}$ : C, 69.66; H, 5.85; N, 9.03; O, 15.47. Found: C, 69.99; $\mathrm{H}, 5.83$; N, 9.05; O, 15.23. Overall yield $12 \%$ ).

\subsubsection{1. ( $S$ )-1a: $(S)$-1-(4-Phenylbenzyl)- $N$-hydroxy-5-oxopyrrol-} idine-2-carboxamide. Amorphous solid- ${ }^{1} \mathrm{H}$ NMR $(300 \mathrm{MHz}$ DMSO- $\left.d_{6}\right): \delta$ 1.83-1.88 (m, $\left.1 \mathrm{H}\right), 2.11-2.21(\mathrm{~m}, 1 \mathrm{H}), 2.29-2.46$ $(\mathrm{m}, 2 \mathrm{H}), 3.65(\mathrm{~d}, 1 \mathrm{H}, J=15.6 \mathrm{~Hz}), 3.82(\mathrm{dd}, 1 \mathrm{H}, J=8.8,3.9 \mathrm{~Hz})$, $4.91(\mathrm{~d}, 1 \mathrm{H}, J=15.6 \mathrm{~Hz}), 7.27(\mathrm{~d}, 2 \mathrm{H}, J=7.8 \mathrm{~Hz}), 7.36$ (dd as t, $1 \mathrm{H}$, $J=14.7,6.86 \mathrm{~Hz}$ ), 7.46 (dd as t, $2 \mathrm{H}, J=14.7,6.86 \mathrm{~Hz}), 7.63(\mathrm{~d}, 2 \mathrm{H}$, $J=7.8 \mathrm{~Hz}$ ), 7.65 (d, 2H, J=5.9 Hz), 9.08 (br s, 1H), 10.79 (br s, 1H). LC-MS (ESI) $\left(\mathrm{H}_{2} \mathrm{O} / \mathrm{CH}_{3} \mathrm{CN}, 1 \%\right.$ TFA $) \mathrm{m} / z(\%): 311.2\left(\mathrm{MH}^{+}, 100\right)$, $\mathrm{C}_{18} \mathrm{H}_{18} \mathrm{~N}_{2} \mathrm{O}_{3}$ : 310.3. Specific optical rotation $[\alpha]_{\mathrm{D}}^{25}+53$ (c 0.02 ,
$\mathrm{CH}_{3} \mathrm{OH}$ ). Anal. Calcd for $\mathrm{C}_{18} \mathrm{H}_{18} \mathrm{~N}_{2} \mathrm{O}_{3}$ : C, 69.66; H, 5.85; N, 9.03; O, 15.47. Found: C, 69.93; H, 5.86; N, 9.04; O, 15.42. Overall yield $15 \%$.

5.2.5.2. $(R)-1 b$ : $(R)-1-(2-C h l o r o b e n z y l)-N$-hydroxy-5-oxopyrrolidine-2-carboxamide. Amorphous solid- $-{ }^{1} \mathrm{H}$ NMR $(300 \mathrm{MHz}$ DMSO- $\left.d_{6}\right): \delta 1.84-1.91(\mathrm{~m}, 1 \mathrm{H}), 2.18-2.27(\mathrm{~m}, 1 \mathrm{H}), 2.29-2.45(\mathrm{~m}$, $2 \mathrm{H}), 3.83-3.87(\mathrm{~m}, 2 \mathrm{H}), 4.79(\mathrm{~d}, 1 \mathrm{H}, J=15.6 \mathrm{~Hz}), 7.21-7.23(\mathrm{~m}$ 1H), 7.32-7.34 (m, 2H), 7.45-7.47 (m, 1H), 9.07 (br s, 1H), 10.74 (br s, 1H). LC-MS (ESI) $\left(\mathrm{H}_{2} \mathrm{O} / \mathrm{CH}_{3} \mathrm{CN}, 1 \% \mathrm{TFA}\right) \mathrm{m} / z$ (\%): $269.1\left(\mathrm{MH}^{+}\right.$, 100), $\mathrm{C}_{12} \mathrm{H}_{13} \mathrm{ClN}_{2} \mathrm{O}_{3}$ : 268.7. Specific optical rotation $[\alpha]_{\mathrm{D}}^{25}-68$ (c $0.09, \mathrm{CH}_{3} \mathrm{OH}$ ). Anal. Calcd for $\mathrm{C}_{12} \mathrm{H}_{13} \mathrm{ClN}_{2} \mathrm{O}_{3}$ : C, 53.64; $\mathrm{H}, 4.88$; $\mathrm{Cl}, 13.19$; N, 10.43; O, 17.86. Found: C, 53.44; $\mathrm{H}, 4.87 ; \mathrm{Cl}, 13.15$; N, 10.45; O, 17.90.

5.2.5.3. (S )-1b: (S)-1-(2-Chlorobenzyl)- $N$-hydroxy-5-oxopyrrolidine-2-carboxamide. Amorphous solid- ${ }^{1} \mathrm{H}$ NMR $(300 \mathrm{MHz}$, DMSO- $\left.d_{6}\right): \delta 1.84-1.92(\mathrm{~m}, 1 \mathrm{H}), 2.16-2.26(\mathrm{~m}, 1 \mathrm{H}), 2.29-2.45$ $(\mathrm{m}, 2 \mathrm{H}), 3.82-3.84(\mathrm{~m}, 1 \mathrm{H}), 3.85(\mathrm{~d}, 1 \mathrm{H}, J=15.6 \mathrm{~Hz}), 4.79(\mathrm{~d}, 1 \mathrm{H}$, $J=15.6 \mathrm{~Hz}), 7.21-7.23(\mathrm{~m}, 1 \mathrm{H}), 7.31-7.34(\mathrm{~m}, 2 \mathrm{H}), 7.45-7.47(\mathrm{~m}$, $1 \mathrm{H}), 9.06$ (br s, $1 \mathrm{H}), 10.75$ (br s, $1 \mathrm{H})$. LC-MS (ESI) $\left(\mathrm{H}_{2} \mathrm{O} / \mathrm{CH}_{3} \mathrm{CN}\right.$, 1\%TFA) $m / z$ (\%): $269.1\left(\mathrm{MH}^{+}, 100\right), \mathrm{C}_{12} \mathrm{H}_{13} \mathrm{ClN}_{2} \mathrm{O}_{3}$ : 268.7. Specific optical rotation $[\alpha]_{\mathrm{D}}^{25}+66$ (c $\left.0.09, \mathrm{CH}_{3} \mathrm{OH}\right)$. Anal. Calcd for $\mathrm{C}_{12} \mathrm{H}_{13} \mathrm{ClN}_{2} \mathrm{O}_{3}$ : C, 53.64; $\mathrm{H}, 4.88 ; \mathrm{Cl}, 13.19 ; \mathrm{N}, 10.43 ; \mathrm{O}, 17.86$ Found: C, 53.50; $\mathrm{H}, 4.87 ; \mathrm{Cl}, 13.17 ; \mathrm{N}, 10.45 ; \mathrm{O}, 17.88$. Overall yield $11 \%$.

5.2.5.4. $(R)-1$ c: $(R)-1-(4-C h l o r o b e n z y l)-N$-hydroxy-5-oxopyrrolidine-2-carboxamide. Amorphous solid- ${ }^{1} \mathrm{H}$ NMR $(300 \mathrm{MHz}$, DMSO- $\left.d_{6}\right): \delta 1.81-1.88(\mathrm{~m}, 1 \mathrm{H}), 2.09-2.19(\mathrm{~m}, 1 \mathrm{H}), 2.26-2.43(\mathrm{~m}$, $2 \mathrm{H}), 3.65(\mathrm{~d}, 1 \mathrm{H}, J=15.6 \mathrm{~Hz}), 3.76(\mathrm{dd}, 1 \mathrm{H}, J=7.8,3.91 \mathrm{~Hz}), 4.79$ $(\mathrm{d}, 1 \mathrm{H}, J=15.6 \mathrm{~Hz}), 7.21(\mathrm{~d}, 2 \mathrm{H}, J=8.8 \mathrm{~Hz}), 7.39(\mathrm{~d}, 2 \mathrm{H}, J=8.8 \mathrm{~Hz})$, 9.08 (br s, $1 \mathrm{H}$ ), 10.74 (br s, $1 \mathrm{H})$. LC-MS (ESI) $\left(\mathrm{H}_{2} \mathrm{O} / \mathrm{CH}_{3} \mathrm{CN}, 1 \% \mathrm{TFA}\right)$ $m / z$ (\%): $269.1\left(\mathrm{MH}^{+}, 100\right), \mathrm{C}_{12} \mathrm{H}_{13} \mathrm{ClN}_{2} \mathrm{O}_{3}$ : 268.7. Specific optical rotation $[\alpha]_{\mathrm{D}}^{25}-55\left(c 0.04, \mathrm{CH}_{3} \mathrm{OH}\right)$. Anal. Calcd for $\mathrm{C}_{12} \mathrm{H}_{13} \mathrm{ClN}_{2} \mathrm{O}_{3}$ : C, 53.64; H, 4.88; Cl, 13.19; N, 10.43; O, 17.86. Found: C, 53.58; $\mathrm{H}, 4.87 ; \mathrm{Cl}, 13.16 ; \mathrm{N}, 10.41 ; \mathrm{O}, 17.82$. Overall yield $13 \%$.

5.2.5.5. ( $S$ )-1c: (S)-1-(4-Chlorobenzyl)- $N$-hydroxy-5-oxopyrrolidine-2-carboxamide. Amorphous solid- ${ }^{1} \mathrm{H}$ NMR $(300 \mathrm{MHz}$, DMSO- $\left.d_{6}\right): \delta$ 1.81-1.89 (m, $\left.1 \mathrm{H}\right), 2.07-2.17(\mathrm{~m}, 1 \mathrm{H}), 2.25-2.41$ $(\mathrm{m}, 2 \mathrm{H}), 3.65(\mathrm{~d}, 1 \mathrm{H}, J=15.6 \mathrm{~Hz}), 3.75(\mathrm{dd}, 1 \mathrm{H}, J=7.8,3.9 \mathrm{~Hz}), 4.78$ $(\mathrm{d}, 1 \mathrm{H}, J=15.6 \mathrm{~Hz}), 7.21(\mathrm{~d}, 2 \mathrm{H}, J=8.8 \mathrm{~Hz}), 7.39(\mathrm{~d}, 2 \mathrm{H}, J=8.8 \mathrm{~Hz})$, 9.11 (br s, $1 \mathrm{H}$ ), 10.82 (br s, $1 \mathrm{H}$ ). LC-MS (ESI) $\left(\mathrm{H}_{2} \mathrm{O} / \mathrm{CH}_{3} \mathrm{CN}, 1 \% \mathrm{TFA}\right)$ $m / z$ (\%): $269.1\left(\mathrm{MH}^{+}, 100\right), \mathrm{C}_{12} \mathrm{H}_{13} \mathrm{ClN}_{2} \mathrm{O}_{3}$ : 268.7. Specific optical rotation $[\alpha]_{D}^{25}+56\left(c 0.04, \mathrm{CH}_{3} \mathrm{OH}\right)$. Anal. Calcd for $\mathrm{C}_{12} \mathrm{H}_{13} \mathrm{ClN}_{2} \mathrm{O}_{3}$ : $\mathrm{C}$, 
53.64; H, 4.88; Cl, 13.19; N, 10.43; O, 17.86. Found: C, 53.61; H, 4.87; $\mathrm{Cl}, 13.18 ; \mathrm{N}, 10.41 ; \mathrm{O}, 17.84$. Overall yield $13 \%$.

\subsubsection{General procedures for the cleavage of carboxylate derivatives 1}

Example: (R)-1-(4-phenylbenzyl)-5-oxopyrrolidine-2-carboxylic acid $\left[(R)-\mathbf{1}^{\prime} \mathbf{a}\right]$.

Functionalized resin derivative $(R)$-14a $(0.04 \mathrm{mmol})$ was swollen in THF $(1.8 \mathrm{ml})$ and cleaved by $\mathrm{NaOH} 0.5 \%$ solution $(2.5 \mathrm{ml}$, $0.37 \mathrm{mmol}$ ). After rocking for $1.5 \mathrm{~h}$ at room temperature, the resin was filtered and the filtrate was evaporated to dryness.

Deprotected $(R)$-1'a was purified by semi-preparative RP-HPLC (C18, Nucleosil $300 \mathrm{~mm} \times 25 \mathrm{~mm}, 3 \mathrm{ml} / \mathrm{min}$, detection at $230 \mathrm{~nm}$, eluent A: Water/TFA: 99.92:0.08, eluent B: acetonitrile/TFA: 99.92:0.08; gradient B from $25 \%$ to $60 \%$ in $13 \mathrm{~min}$, from $60 \%$ to 98 in $1 \mathrm{~min}$ ).

Waxy solid- ${ }^{1} \mathrm{H}$ NMR (300 MHz, DMSO- $\left.d_{6}\right): \delta 1.93-2.0(\mathrm{~m}, 1 \mathrm{H})$, 2.26-2.38 (m, 3H), 3.93-3.98 (m, 2H), $4.91(\mathrm{~d}, 1 \mathrm{H}, J=14.9 \mathrm{~Hz}), 7.29$ $(\mathrm{d}, 2 \mathrm{H}, J=7.8 \mathrm{~Hz}), 7.36(\mathrm{t}, 1 \mathrm{H}, J=7.4 \mathrm{~Hz}), 7.46(\mathrm{t}, 2 \mathrm{H}, J=7.4 \mathrm{~Hz})$, 7.63 (d, 2H, $J=8.2 \mathrm{~Hz}$ ), 7.65 (d, $2 \mathrm{H}, J=7.4 \mathrm{~Hz})$. LC-MS (ESI) $\left(\mathrm{H}_{2} \mathrm{O} /\right.$ $\left.\mathrm{CH}_{3} \mathrm{CN}, 1 \% \mathrm{TFA}\right) \mathrm{m} / z$ (\%): $296.2\left(\mathrm{MH}^{+}, 100\right), \mathrm{C}_{18} \mathrm{H}_{17} \mathrm{NO}_{3}$ : 295.3. Specific optical rotation $[\alpha]_{\mathrm{D}}^{25}-50\left(c 0.01, \mathrm{CH}_{3} \mathrm{OH}\right)$. Anal. Calcd for $\mathrm{C}_{18} \mathrm{H}_{17} \mathrm{NO}_{3}$ : C, 73.20; $\mathrm{H}, 5.80 ; \mathrm{N}, 4.74 ; \mathrm{O}, 16.25$. Found: C, 73.17; $\mathrm{H}, 5.79 ; \mathrm{N}, 4.75 ; \mathrm{O}, 16.26$. Overall yield $15 \%$.

5.2.6.1. (S)-1'a: (S)-1-(4-Phenylbenzyl)- $N$-hydroxy-5-oxopyrrolidine-2-carboxamide. Waxy solid- ${ }^{1} \mathrm{H}$ NMR $(300 \mathrm{MHz}$, DMSO- $\left.d_{6}\right): \delta 1.94-2.0(\mathrm{~m}, 1 \mathrm{H}), 2.26-2.38(\mathrm{~m}, 3 \mathrm{H}), 3.93-3.97$ $(\mathrm{m}, 2 \mathrm{H}), 4.9(\mathrm{~d}, 1 \mathrm{H}, J=15.3 \mathrm{~Hz}), 7.29(\mathrm{~d}, 2 \mathrm{H}, J=8.2 \mathrm{~Hz}), 7.36$ $(\mathrm{t}, 1 \mathrm{H}, J=7.4 \mathrm{~Hz}), 7.46$ (dd as t, $2 \mathrm{H}, J=7.4 \mathrm{~Hz}), 7.63(\mathrm{~d}, 2 \mathrm{H}$, $J=8.2 \mathrm{~Hz}), 7.65(\mathrm{~d}, 2 \mathrm{H}, J=7.8 \mathrm{~Hz})$. LC-MS (ESI) $\left(\mathrm{H}_{2} \mathrm{O} / \mathrm{CH}_{3} \mathrm{CN}\right.$, 1\%TFA) $\mathrm{m} / z$ (\%): $296.2\left(\mathrm{MH}^{+}, 100\right), \mathrm{C}_{18} \mathrm{H}_{17} \mathrm{NO}_{3}$ : 295.3. Specific optical rotation $[\alpha]_{\mathrm{D}}^{25}+56\left(\mathrm{c} 0.05, \mathrm{CH}_{3} \mathrm{OH}\right)$. Anal. Calcd for $\mathrm{C}_{18} \mathrm{H}_{17} \mathrm{NO}_{3}: \mathrm{C}$, 73.20; H, 5.80; N, 4.74; O, 16.25. Found: C, 73.15; H, 5.81; N, 4.75; O, 16.28. Overall yield $17 \%$.

5.2.6.2. (R)-1'b: (R)-1-(2-Chlorobenzyl)-5-oxopyrrolidine-2-carboxylic acid. Waxy solid $-{ }^{1} \mathrm{H}$ NMR $\left(300 \mathrm{MHz}, \mathrm{DMSO}-\mathrm{d}_{6}\right): \delta$ $1.98(\mathrm{~m}, 1 \mathrm{H}), 2.29-2.37(\mathrm{~m}, 3 \mathrm{H}), 3.96(\mathrm{~d}, 1 \mathrm{H}, J=6.3 \mathrm{~Hz}), 4.11(\mathrm{~d}$, $1 \mathrm{H}, J=15.6 \mathrm{~Hz}), 4.85(\mathrm{~d}, 1 \mathrm{H}, J=15.3 \mathrm{~Hz}), 7.24-7.26(\mathrm{~m}, 1 \mathrm{H}), 7.31-$ $7.35(\mathrm{~m}, 2 \mathrm{H}), 7.44-7.48(\mathrm{~m}, 1 \mathrm{H})$. LC-MS (ESI) $\left(\mathrm{H}_{2} \mathrm{O} / \mathrm{CH}_{3} \mathrm{CN}\right.$, 1\%TFA) $m / z$ (\%): $254.1\left(\mathrm{MH}^{+}, 98\right), \mathrm{C}_{12} \mathrm{H}_{12} \mathrm{ClNO}_{3}$ : 253.7. Specific optical rotation $[\alpha]_{\mathrm{D}}^{25}-18\left(\right.$ c $\left.0.07, \mathrm{CH}_{3} \mathrm{OH}\right)$. Anal. Calcd for $\mathrm{C}_{12} \mathrm{H}_{12} \mathrm{ClNO}_{3}$ : C, 56.81; H, 4.77; Cl, 13.98; N, 5.52; O, 18.92. Found: C, 56.94; H, $4.78 ; \mathrm{Cl}, 13.99 ; \mathrm{N}, 5.53 ; \mathrm{O}, 18.96$. Overall yield $18 \%$.

5.2.6.3. (S)-1'b: (S)-1-(2-Chlorobenzyl)-5-oxopyrrolidine-2-carboxylic acid. Waxy solid $-{ }^{1} \mathrm{H}$ NMR $\left(300 \mathrm{MHz}\right.$, DMSO- $\left.d_{6}\right): \delta$ $1.98(\mathrm{~m}, 1 \mathrm{H}), 2.33(\mathrm{~m}, 3 \mathrm{H}), 3.97(\mathrm{~d}, 1 \mathrm{H}, J=6.3 \mathrm{~Hz}), 4.11(\mathrm{~d}, 1 \mathrm{H}$, $J=15.6 \mathrm{~Hz}), 4.85(\mathrm{~d}, 1 \mathrm{H}, J=15.6 \mathrm{~Hz}), 7.25-7.28(\mathrm{~m}, 1 \mathrm{H}), 7.31-$ $7.35(\mathrm{~m}, 2 \mathrm{H}), 7.44-7.48(\mathrm{~m}, 1 \mathrm{H})$. LC-MS (ESI) $\left(\mathrm{H}_{2} \mathrm{O} / \mathrm{CH}_{3} \mathrm{CN}\right.$, 1\%TFA) $m / z$ (\%): $254.1\left(\mathrm{MH}^{+}, 100\right), \mathrm{C}_{12} \mathrm{H}_{12} \mathrm{ClNO}_{3}$ : 253.7. Specific optical rotation $[\alpha]_{\mathrm{D}}^{25}+23\left(\mathrm{c} 0.1, \mathrm{CH}_{3} \mathrm{OH}\right)$. Anal. Calcd for $\mathrm{C}_{12} \mathrm{H}_{12} \mathrm{ClNO}_{3}$ : C, 56.81; $\mathrm{H}, 4.77 ; \mathrm{Cl}, 13.98 ; \mathrm{N}, 5.52 ; \mathrm{O}, 18.92$. Found: C, 56.88; H, 4.78; Cl, 13.97; N, 5.53; O, 18.94. Overall yield $15 \%$.

5.2.6.4. (R)-1'c: (R)-1-(4-Chlorobenzyl)-5-oxopyrrolidine-2-carboxylic acid. Waxy solid $-{ }^{1} \mathrm{H}$ NMR $\left(300 \mathrm{MHz}, \mathrm{DMSO}-\mathrm{d}_{6}\right): \delta$ 1.92-1.98 (m, 1H), 2.22-2.37 (m, 3H), 3.93-3.97 (m, 2H), $4.79(\mathrm{~d}$, $1 \mathrm{H}, J=15.3 \mathrm{~Hz}), 7.23(\mathrm{~d}, 2 \mathrm{H}, J=8.6 \mathrm{~Hz}), 7.39(\mathrm{~d}, 2 \mathrm{H}, J=8.6 \mathrm{~Hz})$. LC-MS (ESI) $\left(\mathrm{H}_{2} \mathrm{O} / \mathrm{CH}_{3} \mathrm{CN}, 1 \% \mathrm{TFA}\right) \mathrm{m} / z$ (\%): $254.1\left(\mathrm{MH}^{+}, 75\right)$, $\mathrm{C}_{12} \mathrm{H}_{12} \mathrm{ClNO}_{3}$ : 253.7. Specific optical rotation $[\alpha]_{\mathrm{D}}^{25}-78$ (c 0.03 , $\mathrm{CH}_{3} \mathrm{OH}$ ). Anal. Calcd for $\mathrm{C}_{12} \mathrm{H}_{12} \mathrm{ClNO}_{3}$ : C, 56.81; H, 4.77; $\mathrm{Cl}, 13.98$; N, 5.52; O, 18.92. Found: C, 56.65; H, 4.76; Cl, 13.94; N, 5.50; O, 18.87. Overall yield $15 \%$.
5.2.6.5. ( $S$ )-1'c: ( $S$ )-1-(4-Chlorobenzyl)-5-oxopyrrolidine-2-carboxylic acid. Waxy solid $-{ }^{1} \mathrm{H}$ NMR $\left(300 \mathrm{MHz}, \mathrm{DMSO}-\mathrm{d}_{6}\right): \delta$ 1.91-1.98 (m, 1H), 2.21-2.37 (m, 3H), $3.91(\mathrm{~d}, 1 \mathrm{H}, J=9.0 \mathrm{~Hz})$, $3.95(\mathrm{~d}, 1 \mathrm{H}, J=15.3 \mathrm{~Hz}), 4.79(\mathrm{~d}, 1 \mathrm{H}, J=15.3 \mathrm{~Hz}), 7.23(\mathrm{~d}, 2 \mathrm{H}$, $J=8.2 \mathrm{~Hz}$ ), 7.39 (d, $2 \mathrm{H}, J=8.2 \mathrm{~Hz}$ ). LC-MS (ESI) $\left(\mathrm{H}_{2} \mathrm{O} / \mathrm{CH}_{3} \mathrm{CN}\right.$, 1\%TFA) $\mathrm{m} / z$ (\%): $254.1\left(\mathrm{MH}^{+}, 75\right), \mathrm{C}_{12} \mathrm{H}_{12} \mathrm{ClNO}_{3}$ : 253.7. Specific optical rotation $[\alpha]_{\mathrm{D}}^{25}+79\left(\mathrm{c} 0.02, \mathrm{CH}_{3} \mathrm{OH}\right)$. Anal. Calcd for $\mathrm{C}_{12} \mathrm{H}_{12} \mathrm{ClNO}_{3}$ : C, 56.81; H, 4.77; Cl, 13.98; N, 5.52; O, 18.92. Found: C, 56.72; H, 4.76; Cl, 13.96; N, 5.50; O, 18.89. Overall yield $14 \%$.

\subsubsection{General procedures for coupling of Fmoc-D/L-Glu-(OAll)- OH to Rink amide resin}

Example: Synthesis of $(R)-\mathbf{1 5}$.

$0.12 \mathrm{mmol}$ of Rink amide resin (Novabiochem) previously Fmoc-deprotected (double treatment of the resin with piperidine $20 \%$ in DMF) were swollen in DCM.

A solution of Fmoc-D-Glu-(OAll)-OH $(R)-11(0.24 \mathrm{~g}, 0.59 \mathrm{mmol})$, 2-(1H-benzotriazole-1-yl)-1,1,3,3-tetramethyluronium hexafluorophosphate (HBTU) $(0.22 \mathrm{~g}, 0.59 \mathrm{mmol}), \mathrm{N}$-hydroxybenzotriazole (HOBt) $(80 \mathrm{mg}, 0.59 \mathrm{mmol})$, and $\mathrm{N}$-methylmorpholine (NMM) $(130 \mu \mathrm{l}, 1.18 \mathrm{mmol})$ in $1 \mathrm{ml}$ dry DMF was introduced into the cartridge. After stirring at room temperature for $2 \mathrm{~h}$, the resin was filtered, rinsed with DMF $(3 \times 5 \mathrm{ml}), \mathrm{DCM}(3 \times 5 \mathrm{ml})$ and TBME $(3 \times 5 \mathrm{ml})$ and finally dried in vacuo.

A positive Kaiser test ${ }^{27}$ resulted, indicating no free amine groups on the resin.

\subsubsection{General procedures for Fmoc deprotection and reductive amination of polymer bound 0 -all-glutamate}

The same procedure described for NovaSynTGOH bound derivatives (Synthesis of $(R)$-13) was followed.

\subsubsection{General procedures for synthesis of polymer bound pyroglutamate ring}

The same procedure described for NovaSynTGOH bound derivatives (synthesis of $(R)$-14a) was followed.

\subsubsection{General procedures for the cleavage of carboxamide derivatives $\mathbf{1}^{\prime \prime}$}

Example: (R)-1-(4-chlorobenzyl)-5-oxopyrrolidine-2-carboxyamide $\left[(R)-\mathbf{1}^{\prime \prime} \mathbf{c}\right]$.

$(R)-17 \mathrm{c}$ was subject to cleavage by treatment with TFA/TIS (95:5) $(120 \mu \mathrm{l}, 2 \mathrm{mmol})$ in order to obtain $(R)-\mathbf{1}^{\prime \prime} \mathbf{c}$ carboxamide. After rocking for $1 \mathrm{~h}$ at room temperature, the resin was filtered and the filtrate was evaporated to dryness.

The crude compound $(R)-\mathbf{1}^{\prime \prime} \mathbf{c}$ did not need further purification as shown by HPLC-MS analysis (97\% of pure compound at $220 \mathrm{~nm} ; 88 \%$ at $254 \mathrm{~nm}$ ).

Waxy solid-1 ${ }^{1} \mathrm{H}$ NMR $\left(300 \mathrm{MHz}\right.$, DMSO- $\left.d_{6}\right): \delta 1.79-1.89(\mathrm{~m}, 1 \mathrm{H})$, 2.05-2.37 (m, 3H), $3.73(\mathrm{~d}, 1 \mathrm{H}, J=15.2 \mathrm{~Hz}), 3.85(\mathrm{dd}, 1 \mathrm{H}, J=8.8$, $3.42 \mathrm{~Hz}$ ), 4.81 (d, $1 \mathrm{H}, J=15.2 \mathrm{~Hz}$ ), 7.16 (br s, $1 \mathrm{H}), 7.21$ (d, $2 \mathrm{H}$, $J=8.3 \mathrm{~Hz}$ ), 7.39 (d, 2H, $J=8.3 \mathrm{~Hz}$ ), 7.55 (br s, 1H). LC-MS (ESI) $\left(\mathrm{H}_{2} \mathrm{O} / \mathrm{CH}_{3} \mathrm{CN}, 1 \% \mathrm{TFA}\right) \mathrm{m} / z$ (\%): $253.2\left(\mathrm{MH}^{+}, 100\right), \mathrm{C}_{12} \mathrm{H}_{13} \mathrm{ClN}_{2} \mathrm{O}_{2}$ : 252.1. Specific optical rotation $[\alpha]_{\mathrm{D}}^{25}-56$ (c $\left.0.04, \mathrm{CH}_{3} \mathrm{OH}\right)$. Anal. Calcd for $\mathrm{C}_{12} \mathrm{H}_{13} \mathrm{ClN}_{2} \mathrm{O}_{2}$ : C, 57.04; $\mathrm{H}, 5.19 ; \mathrm{Cl}, 14.03 ; \mathrm{N}, 11.09 ; \mathrm{O}$, 12.66. Found: C, $57.14 ; \mathrm{H}, 5.20 ; \mathrm{Cl}, 14.05 ; \mathrm{N}, 11.11 ; \mathrm{O}, 12.69$. Overall yield $32 \%$.

5.2.10.1. ( $R$ )-1"a: (R)-1-(4-Phenylbenzyl)-5-oxopyrrolidine-2carboxyamide. Waxy solid $-{ }^{1} \mathrm{H}$ NMR $\left(300 \mathrm{MHz}, \mathrm{DMSO}-d_{6}\right)$ : $\delta$ 1.81-1.89 (m, 1H), 2.07-2.42 (m, 3H), $3.74(\mathrm{~d}, 1 \mathrm{H}, J=15.3 \mathrm{~Hz})$, $3.91(\mathrm{dd}, 1 \mathrm{H}, J=9.0,3.09 \mathrm{~Hz}), 4.93(\mathrm{~d}, 1 \mathrm{H}, J=15.3 \mathrm{~Hz}), 7.19(\mathrm{~s}$, $1 \mathrm{H}), 7.28(\mathrm{~d}, 2 \mathrm{H}, J=8.2 \mathrm{~Hz}), 7.36(\mathrm{t}, 1 \mathrm{H}, J=7.4 \mathrm{~Hz}), 7.46(\mathrm{t}, 2 \mathrm{H}$, $J=7.8 \mathrm{~Hz}), 7.58(\mathrm{~s}, 1 \mathrm{H}), 7.63(\mathrm{~d}, 2 \mathrm{H}, J=7.8 \mathrm{~Hz}), 7.65(\mathrm{~d}, 2 \mathrm{H}$, $J=6.6 \mathrm{~Hz}) . \mathrm{LC}-\mathrm{MS}(\mathrm{ESI})\left(\mathrm{H}_{2} \mathrm{O} / \mathrm{CH}_{3} \mathrm{CN}, 1 \% \mathrm{TFA}\right) \mathrm{m} / z(\%): 295.2\left(\mathrm{MH}^{+}\right.$, 
100), $\mathrm{C}_{18} \mathrm{H}_{18} \mathrm{~N}_{2} \mathrm{O}_{2}$ : 294.3. Specific optical rotation $[\alpha]_{\mathrm{D}}^{25}-66$ (c $0.03, \mathrm{CH}_{3} \mathrm{OH}$ ). Anal. Calcd for $\mathrm{C}_{18} \mathrm{H}_{18} \mathrm{~N}_{2} \mathrm{O}_{2}$ : C, 73.45; $\mathrm{H}, 6.16 ; \mathrm{N}$, 9.52; O, 10.87. Found: C, 73.20; H, 6.17; N, 9.54; O, 10.83. Overall yield $34 \%$.

5.2.10.2. (S)-1"a: (S)-1-(4-Phenylbenzyl)-5-oxopyrrolidine-2-carboxyamide. Waxy solid $-{ }^{1} \mathrm{H}$ NMR $\left(300 \mathrm{MHz}\right.$, DMSO- $\left.d_{6}\right): \delta$ 1.80-1.89 (m, 1H), 2.06-2.41 (m, 3H), $3.73(\mathrm{~d}, 1 \mathrm{H}, J=15.3 \mathrm{~Hz})$, $3.91(\mathrm{dd}, 1 \mathrm{H}, J=9.0,3.91 \mathrm{~Hz}), 4.91(\mathrm{~d}, 1 \mathrm{H}, J=15.3 \mathrm{~Hz}), 7.19$ (s, 1H), 7.27 (d, 2H, J = 7.8 Hz), 7.35 (t, 1H, J= 7.4 Hz), $7.46(\mathrm{t}, 2 \mathrm{H}$, $J=7.4 \mathrm{~Hz}), 7.60(\mathrm{~s}, 1 \mathrm{H}), 7.63(\mathrm{t}, 4 \mathrm{H}, J=6.6 \mathrm{~Hz}) . \mathrm{LC}-\mathrm{MS}(\mathrm{ESI})\left(\mathrm{H}_{2} \mathrm{O} /\right.$ $\mathrm{CH}_{3} \mathrm{CN}, 1 \%$ TFA) $m / z$ (\%): $295.2\left(\mathrm{MH}^{+}, 100\right), \mathrm{C}_{18} \mathrm{H}_{18} \mathrm{~N}_{2} \mathrm{O}_{2}$ : 294.3. Specific optical rotation $[\alpha]_{\mathrm{D}}^{25}+69\left(\mathrm{c} 0.04, \mathrm{CH}_{3} \mathrm{OH}\right.$ ). Anal. Calcd for $\mathrm{C}_{18} \mathrm{H}_{18} \mathrm{~N}_{2} \mathrm{O}_{2}$ : C, 73.45; H, 6.16; N, 9.52; O, 10.87. Found: C, 73.30; $\mathrm{H}, 6.17$; N, 9.53; O, 10.85. Overall yield $37 \%$.

5.2.10.3. (R )-1"b: (R)-1-(2-Chlorobenzyl)-5-oxopyrrolidine-2carboxyamide. Waxy solid- ${ }^{1} \mathrm{H}$ NMR $\left(300 \mathrm{MHz}\right.$, DMSO- $d_{6}$ ): $\delta$ 1.82-1.91 (m, 1H), 2.07-2.37 (m, 3H), 3.89-3.95 (m, $2 \mathrm{H}), 4.84$ (d, $1 \mathrm{H}, J=16.1 \mathrm{~Hz}$ ), 7.16 (br s, $1 \mathrm{H}), 7.24(\mathrm{t}, 1 \mathrm{H}, J=4.4 \mathrm{~Hz}$ ), 7.33 $(\mathrm{t}, 2 \mathrm{H}, J=4.4 \mathrm{~Hz}), 7.46(\mathrm{t}, 1 \mathrm{H}, J=4.4 \mathrm{~Hz}), 7.54$ (br s, 1H). LC-MS (ESI) $\left(\mathrm{H}_{2} \mathrm{O} / \mathrm{CH}_{3} \mathrm{CN}, 1 \% \mathrm{TFA}\right) \mathrm{m} / z$ (\%): $253.2\left(\mathrm{MH}^{+}, 100\right), \mathrm{C}_{12} \mathrm{H}_{13} \mathrm{ClN}_{2} \mathrm{O}_{2}$ : 252.1. Specific optical rotation $[\alpha]_{\mathrm{D}}^{25}-89$ (c $\left.0.03, \mathrm{CH}_{3} \mathrm{OH}\right)$. Anal. Calcd for $\mathrm{C}_{12} \mathrm{H}_{13} \mathrm{ClN}_{2} \mathrm{O}_{2}$ : C, 57.04; $\mathrm{H}, 5.19 ; \mathrm{Cl}, 14.03 ; \mathrm{N}, 11.09 ; \mathrm{O}$, 12.66. Found: C, 56.95; H, 5.18; Cl, 13.98; N, 11.06; O, 12.62. Overall yield $33 \%$.

5.2.10.4. (S)-1"b: (S)-1-(2-Chlorobenzyl)-5-oxopyrrolidine-2-carboxyamide. Waxy solid- ${ }^{1} \mathrm{H}$ NMR $\left(300 \mathrm{MHz}\right.$, DMSO- $\left.d_{6}\right): \delta$ 1.82-1.90 (m, 1H), 2.07-2.37 (m, 3H), 3.89-3.92 (m, 1H), 3.93 (d, $1 \mathrm{H}, J=15.6 \mathrm{~Hz}), 4.84$ (d, 1H, J=15.6 Hz), 7.17 (br s, 1H), 7.24 (t, $1 \mathrm{H}, J=4.9 \mathrm{~Hz}), 7.33(\mathrm{t}, 2 \mathrm{H}, J=4.4 \mathrm{~Hz}), 7.46(\mathrm{t}, 1 \mathrm{H}, J=4.9 \mathrm{~Hz})$, 7.54 (br s, $1 \mathrm{H})$. LC-MS (ESI) $\left(\mathrm{H}_{2} \mathrm{O} / \mathrm{CH}_{3} \mathrm{CN}, 1 \%\right.$ TFA) $\mathrm{m} / z$ (\%): 253.1 $\left(\mathrm{MH}^{+}, 100\right), \mathrm{C}_{12} \mathrm{H}_{13} \mathrm{ClN}_{2} \mathrm{O}_{2}$ : 252.1. Specific optical rotation $[\alpha]_{\mathrm{D}}^{25}$ $+91\left(c 0.05, \mathrm{CH}_{3} \mathrm{OH}\right)$. Anal. Calcd for $\mathrm{C}_{12} \mathrm{H}_{13} \mathrm{ClN}_{2} \mathrm{O}_{2}$ : C, 57.04; $\mathrm{H}$, 5.19; $\mathrm{Cl}, 14.03 ; \mathrm{N}, 11.09 ; \mathrm{O}, 12.66$. Found: $\mathrm{C}, 57.01 ; \mathrm{H}, 5.18 ; \mathrm{Cl}$, 13.99; N, 11.07; O, 12.64. Overall yield 34\%.

5.2.10.5. (S)-1"c: (S)-1-(4-Chlorobenzyl)-5-oxopyrrolidine-2-carboxyamide. Waxy solid- ${ }^{1} \mathrm{H}$ NMR (300 MHz, DMSO$\left.d_{6}+\mathrm{D}_{2} \mathrm{O}\right): \delta$ 1.77-1.85 (m, 1H), 2.14-2.41 (m, 3H), $3.74(\mathrm{~d}, 1 \mathrm{H}$, $J=15.2 \mathrm{~Hz}), \quad 3.89$ (dd, 1H, J=8.8, $3.91 \mathrm{~Hz}), 4.75$ (d, 1H, $J=15.2 \mathrm{~Hz}$ ), 7.17 (d, 2H, $J=8.3 \mathrm{~Hz}), 7.35$ (d, 2H, $J=8.3 \mathrm{~Hz}$ ). LC-MS (ESI) $\left(\mathrm{H}_{2} \mathrm{O} / \mathrm{CH}_{3} \mathrm{CN}, \quad 1 \% \mathrm{TFA}\right) \mathrm{m} / \mathrm{z}$ (\%): $253.1\left(\mathrm{MH}^{+}, \quad 100\right)$, $\mathrm{C}_{12} \mathrm{H}_{13} \mathrm{ClN}_{2} \mathrm{O}_{2}$ : 252.1. Specific optical rotation $[\alpha]_{\mathrm{D}}^{25}+55$ (c 0.03 , $\mathrm{CH}_{3} \mathrm{OH}$ ). Anal. Calcd for $\mathrm{C}_{12} \mathrm{H}_{13} \mathrm{ClN}_{2} \mathrm{O}_{2}$ : C, 57.04; $\mathrm{H}, 5.19 ; \mathrm{Cl}$, 14.03; N, 11.09; O, 12.66. Found: C, 57.10; H, 5.20; Cl, 14.04; N, $11.11 ;$ O, 12.67. Overall yield $31 \%$.

\subsubsection{General procedures for loading Fmoc-NHOH on chlorotritylresin}

Example: Synthesis of 19.

A solution of Fmoc-NHOH ( $51 \mathrm{mg}, 0.2 \mathrm{mmol})$ and DIPEA (70 $\mu \mathrm{l}$, $0.4 \mathrm{mmol}$ ) in $2 \mathrm{ml}$ DCM was dropped on chlorotrityl resin (Novabiochem) $\left(0.2 \mathrm{mmol}\right.$ ) pre-swollen in DCM. ${ }^{28}$

After shaking for $60 \mathrm{~h}$ at room temperature, the resin was filtered and rinsed with DCM $(3 \times 5 \mathrm{ml})$ DMF $(3 \times 5 \mathrm{ml})$, DCM $(3 \times 5 \mathrm{ml})$ and TBME $(3 \times 5 \mathrm{ml})$ and finally dried in vacuo.

The efficiency of loading (loading yield: 53\%) was determined on $3 \mathrm{mg}$ of resin by Fmoc removal analysis (treatment of the resin with piperidine $20 \%$ in DMF) and absorbance measurement at $301 \mathrm{~nm}$ (UV-vis Spectrophotometer Shimadzu).

5.2.12. General procedures for coupling of proline/thioproline/ hydroxyproline rings to - $\mathrm{NHOH}$ functionalized resin

Example: Synthesis of $\mathbf{2 3 .}$
A solution of Fmoc-L-proline $(0.34 \mathrm{~g}, 1 \mathrm{mmol})$, HATU $(0.38 \mathrm{~g}$, $1 \mathrm{mmol})$, and DIPEA ( $348 \mu \mathrm{l}, 2 \mathrm{mmol})$ in $2 \mathrm{ml}$ of dry DMF/DCM (1:1) was added dropwise on the functionalized resin 19 (0.2 mmol) after Fmoc deprotection via classical procedure (20\% Piperidine in DMF for $20 \mathrm{~min}(\times 2))$. The cartridge was shaked for $12 \mathrm{~h}$ at room temperature.

After filtration the resin was rinsed with DMF $(3 \times 5 \mathrm{ml})$, DCM $(3 \times 5 \mathrm{ml})$ and TBME $(3 \times 5 \mathrm{ml})$ and finally dried in vacuo.

The efficiency of loading (loading yield: 53\%) was determined on $3 \mathrm{mg}$ of resin by Fmoc removal analysis (treatment of the resin with piperidine $20 \%$ in DMF) and absorbance measurement at $301 \mathrm{~nm}$ (UV-vis Spectrophotometer Shimadzu).

5.2.13. General procedures for Fmoc deprotection and reductive amination on polymer bound proline/thioproline/ hydroxyproline rings

The same procedure described for the synthesis of $(R)-\mathbf{1 3}$ was followed.

\subsubsection{General procedures for cleavage of hydroxamates derivatives $2 a, 3 a, 4 a$ \\ Example: Synthesis $\mathbf{2 a}$.}

After swelling functionalized resin $\mathbf{2 6}$, the crude product 2a ( $0.1 \mathrm{mmol})$ was cleaved by treatment with $2 \mathrm{ml}$ of AcOH/TFE/ DCM $(1: 1: 8)$ for $1 \mathrm{~h}$ at room temperature. The resin was filtered and the filtrate was evaporated under $\mathrm{N}_{2}$.

The crude product $2 \mathbf{a}$ was further purified by semi-preparative RP-HPLC (C18, Nucleosil $300 \mathrm{~mm} \times 25 \mathrm{~mm}, 3 \mathrm{ml} / \mathrm{min}$, detection at $230 \mathrm{~nm}$, eluent A: Water/TFA: 99.92:0.08, eluent B: acetonitrile/ TFA: $99.92: 0.08$; gradient B from $20 \%$ to $80 \%$ in $14 \mathrm{~min}$, from $80 \%$ to $98 \%$ in $3 \mathrm{~min}$ ).

${ }^{1} \mathrm{H}$ NMR (300 MHz, DMSO- $\left.d_{6}\right)$ : waxy solid- ${ }^{1} \mathrm{H}$ NMR $(300 \mathrm{MHz}$, DMSO- $\left.d_{6}\right): \delta 1.77-1.94(\mathrm{~m}, 2 \mathrm{H}), 2.00-2.13(\mathrm{~m}, 1 \mathrm{H}), 3.14-3.35(\mathrm{~m}$, $1 \mathrm{H}), 3.93-4.04(\mathrm{~m}, 1 \mathrm{H}), 4.10-4.20(\mathrm{~m}, 1 \mathrm{H}), 4.25-4.45(\mathrm{~m}, 3 \mathrm{H})$, 7.38-7.77 (m, 9H), 9.31 (br s, 1H), 11.12 (br s, 1H). LC-MS (ESI) $\left(\mathrm{H}_{2} \mathrm{O} / \mathrm{CH}_{3} \mathrm{CN}, 1 \%\right.$ TFA) $\mathrm{m} / z$ (\%): $297.3\left(\mathrm{MH}^{+}, 100\right), \mathrm{C}_{18} \mathrm{H}_{20} \mathrm{~N}_{2} \mathrm{O}_{2}$ : 296.1. Specific optical rotation $[\alpha]_{\mathrm{D}}^{25}-17$ (c $\left.0.02, \mathrm{CH}_{3} \mathrm{OH}\right)$. Anal. Calcd for $\mathrm{C}_{18} \mathrm{H}_{20} \mathrm{~N}_{2} \mathrm{O}_{2}$ : C, 72.95; H, 6.80; N, 9.45; O, 10.80. Found: C, 73.98; H, 6.79; N, 9.46; O, 10.77. Overall yield $22 \%$.

5.2.14.1. Compound 3a. Waxy solid- ${ }^{1} \mathrm{H}$ NMR $(300 \mathrm{MHz}$, DMSO- $\left.d_{6}\right): \delta 3.10(\mathrm{~s}, 3 \mathrm{H}), 3.89-3.91(\mathrm{~m}, 1 \mathrm{H}), 3.95-4.00(\mathrm{~m}, 1 \mathrm{H})$, 4.06-4.09 (m, 1H), 4.23-4.28 (m, 1H), 4.44-4.47 (m, 1H), 7.37$7.70(\mathrm{~m}, 9 \mathrm{H}), 9.88-9.99(\mathrm{~m}, 1 \mathrm{H}), 11.26$ (br s, 1H). LC-MS (ESI) $\left(\mathrm{H}_{2} \mathrm{O} / \mathrm{CH}_{3} \mathrm{CN}, 1 \% \mathrm{TFA}\right) \mathrm{m} / \mathrm{z}(\%)$ : $315.2\left(\mathrm{MH}^{+}, 100\right), \mathrm{C}_{17} \mathrm{H}_{18} \mathrm{~N}_{2} \mathrm{O}_{2} \mathrm{~S}$ : 314.1.

Specific optical rotation $[\alpha]_{\mathrm{D}}^{25}-8\left(c 0.06, \mathrm{CH}_{3} \mathrm{OH}\right)$. Anal. Calcd for $\mathrm{C}_{17} \mathrm{H}_{18} \mathrm{~N}_{2} \mathrm{O}_{2} \mathrm{~S}$ : C, 64.94; H, 5.77; N, 8.91; O, 10.18; S, 10.20. Found: C, 64.71; H, 5.76; N, 8.93; O, 10.22; S, 10.25. Overall yield $20 \%$.

5.2.14.2. 4a: (2S,4R)- $N, 4$-Dihydroxy-1-benzyl(4' -phenyl)-pyrrolidine-2-carboxamide. Waxy solid- ${ }^{1} \mathrm{H}$ NMR (300 MHz, DMSO$\left.d_{6}\right): \delta 1.99-2.10(\mathrm{~m}, 1 \mathrm{H}), 2.15-2.27(\mathrm{~m}, 1 \mathrm{H}), 3.03-3.17(\mathrm{~m}, 1 \mathrm{H}), 3.55-$ $3.70(\mathrm{~m}, 2 \mathrm{H}), 4.10-4.20(\mathrm{~m}, 1 \mathrm{H}), 4.33-4.49(\mathrm{~m}, 3 \mathrm{H}), 7.38-7.76$ (m, 9H), 9.29 (br s, 1H), 11.06 (br s, $1 \mathrm{H})$. LC-MS (ESI) $\left(\mathrm{H}_{2} \mathrm{O} / \mathrm{CH}_{3} \mathrm{CN}\right.$, 1\%TFA) $m / z$ (\%): $313.2\left(\mathrm{MH}^{+}, 100\right), \mathrm{C}_{18} \mathrm{H}_{20} \mathrm{~N}_{2} \mathrm{O}_{3}: 312.5$.

Specific optical rotation $[\alpha]_{\mathrm{D}}^{25}-2\left(c 0.1, \mathrm{CH}_{3} \mathrm{OH}\right)$. Anal Calcd for $\mathrm{C}_{18} \mathrm{H}_{20} \mathrm{~N}_{2} \mathrm{O}_{3}$ : C, 69.21; H, 6.45; N, 8.97; O, 15.37. Found: C, 69.10; $\mathrm{H}, 6.43$; N, 8.79; O, 15.40. Overall yield $27 \%$.

\subsubsection{General procedures for coupling of Fmoc-D-Cys-(trt)-OH to NovaSynTGOH resin}

A solution of Fmoc-D-Cys-(trt)-OH (1.02 g, $1.7 \mathrm{mmol})$, HATU $(0.65 \mathrm{~g}, 1.7 \mathrm{mmol})$, and DIEA $(600 \mu \mathrm{l}, 3.4 \mathrm{mmol})$ in $3 \mathrm{ml}$ of dry DMF was dropped on the resin NovaSynTGOH (1.12 g, $0.34 \mathrm{mmol})$. 
DMAP ( $8.5 \mathrm{mg}, 0.2 \mathrm{mmol}$ ) in $0.5 \mathrm{ml}$ of dry DMF was added, and the cartridge was shaked at room temperature for $6 \mathrm{~h}$.

After filtration of the solution the resin was rinsed with DMF $(3 \times 5 \mathrm{ml})$, DCM $(3 \times 5 \mathrm{ml})$ and TBME $(3 \times 5 \mathrm{ml})$ and finally dried in vacuo.

The efficiency of loading (loading yield: 80\%) was determined on $8.3 \mathrm{mg}$ of resin by Fmoc removal analysis (treatment of the resin with piperidine 20\% in DMF) and absorbance measurement at $301 \mathrm{~nm}$ (UV-vis Spectrophotometer Shimadzu).

\subsubsection{General procedures for Fmoc deprotection and reductive amination}

The same procedure described for the synthesis of $(R)-\mathbf{1 3}$ was followed.

\subsubsection{General procedures for trityl deprotection and cyclization}

Trityl deprotection of $\mathbf{3 1}$ (0.04 mmol pre-swollen in DCM) was performed with TFA/triisopropyl silane (TIS)/DCM 10:5:85 (4× $30 \mathrm{~min}$ ). Then the resin was filtered, rinsed with DCM and a solution of $10 \% \mathrm{Et}_{3} \mathrm{~N}$ in DMF was added.

After filtering and washing (DMF, DCM), a solution of CDI (60 $\mathrm{mg}, 0.37 \mathrm{mmol}$ ) dissolved in $1 \mathrm{ml}$ dry DCM was introduced into the cartridge; the cyclization proceeded for $6 \mathrm{~h}$ at room temperature. Functionalized resin $\mathbf{3 2}$ was then rinsed with DCM $(\times 3)$, $\operatorname{DMF}(\times 3), \operatorname{DCM}(\times 3)$, and TBME $(\times 3)$.

\subsubsection{General procedures for the cleavage of hydroxamate derivatives $5 a$}

The same procedure described for $(R)-\mathbf{1 a}$ was followed.

Compound 5a: Amorphous solid- ${ }^{1} \mathrm{H}$ NMR (300 MHz, DMSO- $d_{6}$ ): $\delta$ 3.19-3.24 (m, 1H), 3.60 (dd, $1 \mathrm{H}, J=8.6,10.9 \mathrm{~Hz}), 3.83(\mathrm{~d}, 1 \mathrm{H}$, $J=15.1 \mathrm{~Hz}), 4.09-4.19(\mathrm{~m}, 1 \mathrm{H}), 4.89(\mathrm{~d}, 1 \mathrm{H}, J=15.7 \mathrm{~Hz}), 7.28-$ $7.41(\mathrm{~m}, 3 \mathrm{H}), 7.42-7.51(\mathrm{~m}, 2 \mathrm{H}), 7.66(\mathrm{~d}, 4 \mathrm{H} \mathrm{J}=8.1 \mathrm{~Hz}), 9.21(\mathrm{~s}$, $1 \mathrm{H}), 10.89$ (s, 1H). LC-MS (ESI) $\left(\mathrm{H}_{2} \mathrm{O} / \mathrm{CH}_{3} \mathrm{CN}, 1 \% \mathrm{TFA}\right) \mathrm{m} / \mathrm{z}(\%)$ : 329.2 $\left(\mathrm{MH}^{+}, 10\right), \mathrm{C}_{17} \mathrm{H}_{18} \mathrm{~N}_{2} \mathrm{O}_{6} \mathrm{~S}_{2}$ : 328.4. Specific optical rotation $[\alpha]_{D}^{25}-37$ (c 0.03, $\left.\mathrm{CH}_{3} \mathrm{OH}\right)$. Anal. Calcd for $\mathrm{C}_{17} \mathrm{H}_{16} \mathrm{~N}_{2} \mathrm{O}_{3} \mathrm{~S}: \mathrm{C}, 62.18$; $\mathrm{H}, 4.91$; N, 8.53; O, 14.62; S, 9.76. Found: C, 62.16; H, 4.87; N, 8.58 ; O, 14.64; S, 9.78. Overall yield 35\%.

\subsubsection{General procedure for synthesis of Fmoc-D-Glu(OAll)- NHOH and loading on chlorotrityl resin}

A solution of Fmoc-D-Glu-(OAll) chloride (obtained by the reaction between Fmoc-D-Glu-(OAll)-OH (0.32 g, $0.77 \mathrm{mmol}$ ) and $\mathrm{SOCl}_{2}$ $(1.5 \mathrm{ml}, 21 \mathrm{mmol})$ in dioxane for $2.5 \mathrm{~h}$ at $\left.50{ }^{\circ} \mathrm{C}\right)$ in $1 \mathrm{ml}$ of dioxane was added to a freshly prepared solution of hydroxylamine, obtained by reaction between hydroxylamine hydrochloride $(0.27 \mathrm{~g}$, $3.85 \mathrm{mmol})$ and DIEA (690 $\mu \mathrm{l}, 3.85 \mathrm{mmol})$ in dioxane/water. After being stirred at room temperature overnight, the mixture was evaporated under reduced pressure and DCM and $\mathrm{HCl} 0.1 \mathrm{M}$ solution were added. The organic layer was separated, and the aqueous one was extracted with DCM $(2 \times 5 \mathrm{~mL})$. The combined organic solutions were dried $\left(\mathrm{MgSO}_{4}\right)$, and evaporated to dryness.

A solution of the pure compound $33(95.7 \% 220 \mathrm{~nm}, 91.2 \%$ $254 \mathrm{~nm})(0.15 \mathrm{mg}, 0.35 \mathrm{mmol})$ and DIEA ( $165 \mu \mathrm{l}, 0.92 \mathrm{mmol})$ in $3 \mathrm{ml}$ DMF/DCM (1:10) was added dropwise on chlorotrityl resin (Novabiochem) (160 mg, $0.23 \mathrm{mmol}$ ) pre-swollen in DCM. After shaking for $60 \mathrm{~h}$ at room temperature, the resin was filtered and rinsed first with $\mathrm{DCM} / \mathrm{MeOH} / \mathrm{DIEA}(17: 2: 1)(3 \times 5 \mathrm{~min})$ and later with DCM $(3 \times 5 \mathrm{ml})$, DMF $(3 \times 5 \mathrm{ml})$, DCM $(3 \times 5 \mathrm{ml})$ and TBME $(3 \times 5 \mathrm{ml})$ and finally dried in vacuo. The efficiency of loading (loading yield: 60\%) was determined on $2.8 \mathrm{mg}$ of resin by Fmoc removal analysis (treatment of the resin with piperidine $20 \%$ in DMF) and absorbance measurement at $301 \mathrm{~nm}$ (UV-vis Spectrophotometer Shimadzu).

\subsubsection{General procedures for Fmoc deprotection and $N$ - sulphonylation}

After Fmoc deprotection of $(R)-34$ with 20\% piperidine in DMF for $20 \mathrm{~min}(\times 2)$, the resin $(70 \mathrm{mg}, 0.07 \mathrm{mmol})$ was washed $(2 \times$ DMF, $2 \times \mathrm{DCM})$, and DIEA $(0.41 \mathrm{mmol}, 73 \mu \mathrm{l})$ and a solution of bisphenylsulfonyl chloride $(0.27 \mathrm{mmol}, 68 \mathrm{mg})$ in $1.5 \mathrm{ml}$ of dry DCM (11 mg, $0.09 \mathrm{mmol}$ ) were added dropwise. After shaking overnight at room temperature, the resin was filtered and rinsed with DCM $(\times 3)$, DMF $(\times 3), \mathrm{DCM}(\times 3)$ and TBME $(\times 3)$.

\subsubsection{General procedures for allyl deprotection and cyclization The same procedure described for $(R)-\mathbf{1 4}$ was followed.}

\subsubsection{General procedures for cleavage of hydroxamates 6 a}

The crude product $\mathbf{6 a}$ was cleaved by treatment of $\mathbf{3 6 a}$ with $2.5 \mathrm{ml}$ of TFA (5\%) in DCM for $2 \mathrm{~h}$ at room temperature. The resin was then filtered and filtrate was evaporated under $\mathrm{N}_{2}$.

6a was further purified by semi-preparative RP-HPLC (C18, Nucleosil $300 \mathrm{~mm} \times 25 \mathrm{~mm}, 3 \mathrm{ml} / \mathrm{min}$, detection at $230 \mathrm{~nm}$, eluent A: Water/TFA: 99.92:0.08, eluent B: acetonitrile/TFA: 99.92:0.08; gradient B from $20 \%$ to $80 \%$ in $14 \mathrm{~min}$, from $80 \%$ to $98 \%$ in $3 \mathrm{~min}$ ).

Amorphous solid- ${ }^{1} \mathrm{H}$ NMR (300 MHz, DMSO- $d_{6}$ ): $\delta$ 1.84-1.97 $(\mathrm{m}, 1 \mathrm{H}), 2.23-2.49(\mathrm{~m}, 3 \mathrm{H}), 4.67(\mathrm{~d}, 1 \mathrm{H}, J=8.1 \mathrm{~Hz}), 7.42-7.59(\mathrm{~m}$, $3 \mathrm{H}), 7.7(\mathrm{~d}, 2 \mathrm{H}, J=7.6 \mathrm{~Hz}), 7.91(\mathrm{~d}, 2 \mathrm{H} J=8.7 \mathrm{~Hz}), 8.04(\mathrm{~d}, 2 \mathrm{H}$ $J=8.7 \mathrm{~Hz}), 9.18(\mathrm{~s}, 1 \mathrm{H}), 11(\mathrm{~s}, 1 \mathrm{H})$. LC-MS (ESI) $\left(\mathrm{H}_{2} \mathrm{O} / \mathrm{CH}_{3} \mathrm{CN}\right.$, 1\%TFA) $\mathrm{m} / \mathrm{z}$ (\%): $361.2\left(\mathrm{MH}^{+}, 75\right), \mathrm{C}_{17} \mathrm{H}_{16} \mathrm{~N}_{2} \mathrm{O}_{5} \mathrm{~S}$ : 360.4. Specific optical rotation $[\alpha]_{D}^{25}+11\left(c 0.02, \mathrm{CH}_{3} \mathrm{OH}\right)$. Anal. Calcd for $\mathrm{C}_{17} \mathrm{H}_{16} \mathrm{~N}_{2} \mathrm{O}_{5} \mathrm{~S}$ : C, 56.66; H, 4.47; N, 7.77; O, 22.20; S, 8.90. Found: C, 56.55; H, 4.49; N, 7.80; O, 22.22; S, 8.92. Overall yield $12 \%$.

\subsubsection{General procedure for synthesis of series $7,8,9,10$}

The synthesis of $\mathbf{7 , 8}$ series was realized according to a common parallel strategy except for the coupling to NovaSynTGOH resin: $\mathrm{N}$-Fmoc proline and $\mathrm{N}$-Fmoc thioproline were loaded respectively via HATU and via fluoride. The subsequent synthetic steps were performed with the same experimental procedures.

\subsubsection{General procedures for coupling of $\mathrm{N}$-Fmoc proline to NovaSynTGOH \\ Example: Synthesis of $\mathbf{3 7}$.}

A solution of Fmoc-L-proline $(0.34 \mathrm{~g}, 1 \mathrm{mmol})$, HATU (0.38 g, $1 \mathrm{mmol}$ ), and DIPEA (348 $\mu \mathrm{l}, 2 \mathrm{mmol})$ in $2 \mathrm{ml}$ of dry DMF/DCM (1:1) was dropped on the resin NovaSynTGOH $(0.2 \mathrm{mmol})$.

The cartridge was rocked $12 \mathrm{~h}$ at room temperature.

After filtration the resin was rinsed with DMF $(3 \times 5 \mathrm{ml}), \mathrm{DCM}$ $(3 \times 5 \mathrm{ml})$ and TBME $(3 \times 5 \mathrm{ml})$ and finally dried in vacuo.

The efficiency of loading (loading yield: $80 \%$ ) was determined on $8.3 \mathrm{mg}$ of resin by Fmoc removal analysis (treatment of the resin with piperidine $20 \%$ in DMF) and absorbance measurement at $301 \mathrm{~nm}$ (UV-vis Spectrophotometer Shimadzu).

\subsubsection{General procedures for coupling of $\mathbf{N}$-Fmoc thiazolidine to NovaSynTGOH}

Example: Synthesis of $\mathbf{3 8}$.

A solution of $N$-Fmoc thiazolidine $(0.34 \mathrm{~g}, 1 \mathrm{mmol})$, HATU ( $0.38 \mathrm{~g}, 1 \mathrm{mmol})$, and DIPEA ( $348 \mu \mathrm{l}, 2 \mathrm{mmol})$ in $2 \mathrm{ml}$ of dry DMF/ DCM (1:1) was added dropwise on was added to NovaSynTGOH $(0.2 \mathrm{mmol})$ after Fmoc deprotection via classical procedure $(20 \%$ Piperidine in DMF for 20 min $(\times 2))$. The cartridge was shaked for $12 \mathrm{~h}$ at room temperature.

After filtration the resin was rinsed with DMF $(3 \times 5 \mathrm{ml}), \mathrm{DCM}$ $(3 \times 5 \mathrm{ml})$ and TBME $(3 \times 5 \mathrm{ml})$ and finally dried in vacuo.

The efficiency of loading (loading yield: $53 \%$ ) was determined on $3 \mathrm{mg}$ of resin by Fmoc removal analysis (treatment of the resin with piperidine $20 \%$ in DMF) and absorbance measurement at $301 \mathrm{~nm}$ (UV-vis Spectrophotometer Shimadzu). 


\subsubsection{General procedures for $\mathrm{N}$-sulphonylation of polymer bound proline/thioproline \\ Example: Synthesis of 40a.}

After Fmoc deprotection with 20\% piperidine in DMF for 20 min $(\times 2), 39(0.03 \mathrm{mmol})$ was washed $(2 \times \mathrm{DMF}, 2 \times \mathrm{DCM})$ and preswollen in $2 \mathrm{ml}$ of THF in presence of DMAP $(3.4 \mathrm{mg}, 0.03 \mathrm{mmol})$. A solution of bisphenylsulphonylchloride $(0.14 \mathrm{mmol})$ in $1 \mathrm{ml}$ of dry DCM was added and the cartridge was rocked for $12 \mathrm{~h}$ at room temperature.

Then the resin was filtered and washed with $\mathrm{MeOH}(\times 2)$, DMF $(\times 2)$, DCM $(\times 2)$ and TBME $(\times 2)$.

\subsubsection{General procedures for cleavage of hydroxamate derivatives 7,8}

Example: Synthesis of $\mathbf{8 a}$.

Functionalized resin derivative $40 \mathrm{a}(0.03 \mathrm{mmol})$ was swollen in THF $(1.8 \mathrm{ml})$ and cleaved by solid support by treatment with $50 \%$ $\mathrm{NH}_{2} \mathrm{OH}$ in $\mathrm{H}_{2} \mathrm{O}(300 \mu \mathrm{l}, 5.6 \mathrm{mmol})$. After rocking for $5 \mathrm{~h}$ at room temperature, the resin was filtered and the filtrate was evaporated to dryness.

The crude product 8a was further purified by semi-preparative RP-HPLC (C18, Nucleosil $300 \mathrm{~mm} \times 25 \mathrm{~mm}, 3 \mathrm{ml} / \mathrm{min}$, detection at $230 \mathrm{~nm}$, eluent A: Water/TFA: 99.92:0.08, eluent B: acetonitrile/ TFA: 99.92:0.08; gradient B from $20 \%$ to $80 \%$ in 14 min, from $80 \%$ to $98 \%$ in $3 \mathrm{~min}$ ).

5.2.27.1. Compound 8a. Amorphous solid- ${ }^{1} \mathrm{H}$ NMR $\left(300 \mathrm{MHz}\right.$, DMSO $\left.-d_{6}\right): \delta 2.83-2.93(\mathrm{~m}, 1 \mathrm{H}), 2.97-3.04(\mathrm{~m}, 1 \mathrm{H})$, $4.46(\mathrm{~d}, 1 \mathrm{H}, J=10.8 \mathrm{~Hz}), 4.52(\mathrm{dd}, 1 \mathrm{H}, J=5.9,7.57 \mathrm{~Hz}), 4.85$ (d, $1 \mathrm{H}, J=10.8 \mathrm{~Hz}), 7.44-7.57(\mathrm{~m}, 3 \mathrm{H}), 7.79(\mathrm{~d}, 2 \mathrm{H}, J=7.6 \mathrm{~Hz})$, 7.91-8.03 (m, 4H), $9.05(\mathrm{~s}, 1 \mathrm{H}), 10.87(\mathrm{~s}, 1 \mathrm{H})$. LC-MS (ESI) $\left(\mathrm{H}_{2} \mathrm{O} /\right.$ $\left.\mathrm{CH}_{3} \mathrm{CN}, 1 \% \mathrm{TFA}\right) \mathrm{m} / z$ (\%): $365.2\left(\mathrm{MH}^{+}, 100\right), \mathrm{C}_{16} \mathrm{H}_{16} \mathrm{~N}_{2} \mathrm{O}_{4} \mathrm{~S}_{2}$ : 364.4 . Specific optical rotation $[\alpha]_{\mathrm{D}}^{25}-125\left(c \quad 0.03, \mathrm{CH}_{3} \mathrm{OH}\right)$. Anal. Calcd for $\mathrm{C}_{16} \mathrm{H}_{16} \mathrm{~N}_{2} \mathrm{O}_{5} \mathrm{~S}$ : C, 50.51; H, 4.24; N, 7.36; O, 21.03; S, 16.86 . Found: C, 50.60; H, 4.25; N, 7.41; O, 21.06; S, 16.90. Overall yield $34 \%$.

5.2.27.2. Compound 7a. Amorphous solid $-{ }^{1} \mathrm{H}$ NMR $\left(300 \mathrm{MHz}\right.$, DMSO- $\left.d_{6}\right): \delta$ 1.45-1.58 $(\mathrm{m}, 1 \mathrm{H}), 1.67-1.93(\mathrm{~m}, 3 \mathrm{H})$, 3.14-3.26 (m, 1H), 3.38-3.49 (m, $1 \mathrm{H}), 3.98(\mathrm{dd}, 1 \mathrm{H}, J=4.4$, $8.12 \mathrm{~Hz}), 7.44-7.57(\mathrm{~m}, 3 \mathrm{H}), 7.77(\mathrm{~d}, 2 \mathrm{H}, J=7.6 \mathrm{~Hz}), 7.93(\mathrm{~s}, 4 \mathrm{H})$, $8.95(\mathrm{~s}, 1 \mathrm{H}), 10.70(\mathrm{~s}, 1 \mathrm{H})$. LC-MS (ESI) $\left(\mathrm{H}_{2} \mathrm{O} / \mathrm{CH}_{3} \mathrm{CN}, 1 \% \mathrm{TFA}\right) \mathrm{m} / \mathrm{z}$ (\%): $347.2\left(\mathrm{MH}^{+}, 45\right), \mathrm{C}_{17} \mathrm{H}_{18} \mathrm{~N}_{2} \mathrm{O}_{4} \mathrm{~S}$ : 346.4. Specific optical rotation $[\alpha]_{D}^{25}-110\left(c 0.04, \mathrm{CH}_{3} \mathrm{OH}\right)$. Anal Calcd for: $\mathrm{C}_{17} \mathrm{H}_{18} \mathrm{~N}_{2} \mathrm{O}_{4} \mathrm{~S}$ : C, 58.94; H, 5.24; N, 8.09; O, 18.48; S, 9.26. Found: C, 58.88; H, 5.21; N, 8.12; O, 18.50; S, 9.21. Overall yield $38 \%$.

5.2.27.3. Compound 8h. Amorphous solid $-{ }^{1} \mathrm{H}$ NMR $\left(300 \mathrm{MHz}\right.$, DMSO $\left.-d_{6}\right): \delta 2.75-2.83(\mathrm{~m}, 1 \mathrm{H}), 2.98(\mathrm{dd}, 1 \mathrm{H}, J=5.4$, $11.36 \mathrm{~Hz}$ ), 4.47 (d, $1 \mathrm{H}, J=10.8), 4.57$ (dd, $1 \mathrm{H}, J=5.4,7.03 \mathrm{~Hz}), 4.9$ (d, 3H), 7.67-7.79 (m, 2H), 7.90-7.96 (m, 1H), 8.05-8.23 (m, 3H), $8.60(\mathrm{~s}, 1 \mathrm{H}), 8.71(\mathrm{~s}, 1 \mathrm{H}), 9.11(\mathrm{~s}, 1 \mathrm{H})$. LC-MS (ESI) $\left(\mathrm{H}_{2} \mathrm{O} / \mathrm{CH}_{3} \mathrm{CN}\right.$, 1\%TFA) $m / z$ (\%): $339.2\left(\mathrm{MH}^{+}, 100\right), \mathrm{C}_{14} \mathrm{H}_{14} \mathrm{~N}_{2} \mathrm{O}_{4} \mathrm{~S}_{2}$ : 338.4. Specific optical rotation $[\alpha]_{\mathrm{D}}^{25}-80$ (c $\left.0.06, \mathrm{CH}_{3} \mathrm{OH}\right)$. Anal Calcd for $\mathrm{C}_{14} \mathrm{H}_{14} \mathrm{~N}_{2} \mathrm{O}_{5} \mathrm{~S}_{2}$ : C, 47.45; H, 3.98; N, 7.90; O, 22.57; S, 18.10. Found: C, 47.42; H, 4.00; N, 7.99; O, 22.49; S, 18.12. Overall yield $35 \%$.

5.2.27.4. 8i-TFA salt. Amorphous solid $-{ }^{1} \mathrm{H}$ NMR $(300 \mathrm{MHz}$, DMSO- $\left.d_{6}\right): \delta 2.80-2.89(\mathrm{~m}, 1 \mathrm{H}), 2.99(\mathrm{dd}, 1 \mathrm{H}, J=3.8,11.36 \mathrm{~Hz}$ ), $4.44(\mathrm{~d}, 1 \mathrm{H}, J=9.7), 4.95$ (d, $1 \mathrm{H}, J=9.7 \mathrm{~Hz}), 5.27$ (dd, $1 \mathrm{H}, J=4.3$, $7.6 \mathrm{~Hz}), 7.72-7.84(\mathrm{~m}, 2 \mathrm{H}), 8.37(\mathrm{~d}, 1 \mathrm{H}, J=8.1 \mathrm{~Hz}), 8.46(\mathrm{~d}, 1 \mathrm{H}$, $J=7.0 \mathrm{~Hz}$ ), 8.58 (d, $1 \mathrm{H}, J=8.1 \mathrm{~Hz}), 9.09(\mathrm{~d}, 1 \mathrm{H}, J=4.3 \mathrm{~Hz}), 10.75$ (s, 1H), $11.05(\mathrm{~s}, 1 \mathrm{H}), 12.19(\mathrm{~s}, 1 \mathrm{H})$. LC-MS (ESI) $\left(\mathrm{H}_{2} \mathrm{O} / \mathrm{CH}_{3} \mathrm{CN}\right.$, 1\%TFA) $m / z$ (\%): $340.2\left(\mathrm{MH}^{+}-\mathrm{CF}_{3} \mathrm{CO}_{2}{ }^{-}, 100\right), \mathrm{C}_{15} \mathrm{H}_{14} \mathrm{~F}_{3} \mathrm{~N}_{3} \mathrm{O}_{6} \mathrm{~S}_{2}$ : 453.4. Specific optical rotation $[\alpha]_{\mathrm{D}}^{25}-66\left(\mathrm{c} 0.05, \mathrm{CH}_{3} \mathrm{OH}\right)$. Anal Calcd for $\mathrm{C}_{15} \mathrm{H}_{14} \mathrm{~F}_{3} \mathrm{~N}_{3} \mathrm{O}_{7} \mathrm{~S}_{2}$ : C, 38.38; $\mathrm{H}, 3.01 ; \mathrm{F}, 12.14 ; \mathrm{N}, 8.95 ; \mathrm{O}$,
23.86; S, 13.66. Found: C, 38.41; H, 3.01; F, 12.16; N, 8.98; O 23.90; S, 13.63. Overall yield $25 \%$.

5.2.27.5. Compound 8 j. Amorphous solid- ${ }^{1} \mathrm{H}$ NMR $\left(300 \mathrm{MHz}\right.$, DMSO- $\left.d_{6}\right): \delta 2.81-2.88(\mathrm{~m}, 1 \mathrm{H}), 3.0(\mathrm{dd}, 1 \mathrm{H}, J=5.4$ $11.90 \mathrm{~Hz}), 4.39-4.49(\mathrm{~m}, 2 \mathrm{H}), 4.75(\mathrm{~d}, 1 \mathrm{H}, J=10.8 \mathrm{~Hz}), 7-7.08(\mathrm{~m}$ $4 \mathrm{H}), 7.13(\mathrm{~d}, 2 \mathrm{H}, J=9.2 \mathrm{~Hz}), 7.87(\mathrm{~d}, 2 \mathrm{H}, J=8.7 \mathrm{~Hz}), 9.07(\mathrm{br} \mathrm{s}$ $2 \mathrm{H})$. LC-MS (ESI) $\left(\mathrm{H}_{2} \mathrm{O} / \mathrm{CH}_{3} \mathrm{CN}, 1 \% \mathrm{TFA}\right) \mathrm{m} / \mathrm{z}(\%): 411.1\left(\mathrm{MH}^{+}, 45\right)$ $\mathrm{C}_{17} \mathrm{H}_{18} \mathrm{~N}_{2} \mathrm{O}_{6} \mathrm{~S}_{2}$ : 410.5. Specific optical rotation $[\alpha]_{D}^{25}-22$ (c 0.1 , $\mathrm{CH}_{3} \mathrm{OH}$ ). Anal Calcd for $\mathrm{C}_{17} \mathrm{H}_{18} \mathrm{~N}_{2} \mathrm{O}_{7} \mathrm{~S}_{2}$ : C, 47.88; H, 4.25; N, 6.57; O, 26.26; S, 15.04. Found: C, 47.81; H, 4.26; N, 6.51; O, 26.23; S, 15.05. Overall yield $29 \%$.

5.2.27.6. Compound 8k. Amorphous solid $-{ }^{1} \mathrm{H}$ NMR $\left(300 \mathrm{MHz}\right.$, DMSO- $\left.d_{6}\right): \delta 2.70-2.80(\mathrm{~m}, 1 \mathrm{H}), 2.98-3.05(\mathrm{~m}, 1 \mathrm{H})$, $4.40-4.52(\mathrm{~m}, 2 \mathrm{H}), 4.72(\mathrm{~d}, 1 \mathrm{H}, J=10.3 \mathrm{~Hz}), 7.09-7.24(\mathrm{~m}, 4 \mathrm{H})$, $7.53(\mathrm{~d}, 2 \mathrm{H}, J=8.7 \mathrm{~Hz}), 7.91(\mathrm{~d}, 2 \mathrm{H}, J=8.7 \mathrm{~Hz}), 8.61-8.93(\mathrm{br} \mathrm{s}$, $2 \mathrm{H})$. LC-MS (ESI) $\left(\mathrm{H}_{2} \mathrm{O} / \mathrm{CH}_{3} \mathrm{CN}, 1 \% \mathrm{TFA}\right) \mathrm{m} / z(\%): 415.1\left(\mathrm{MH}^{+}, 90\right)$ $\mathrm{C}_{16} \mathrm{H}_{15} \mathrm{ClN}_{2} \mathrm{O}_{5} \mathrm{~S}_{2}$ : 414.9. Specific optical rotation $[\alpha]_{\mathrm{D}}^{25}-21$ (c 0.1 , $\mathrm{CH}_{3} \mathrm{OH}$ ). Anal. Calcd for $\mathrm{C}_{16} \mathrm{H}_{15} \mathrm{ClN}_{2} \mathrm{O}_{6} \mathrm{~S}_{2}: \mathrm{C}, 44.60 ; \mathrm{H}, 3.51 ; \mathrm{Cl}$, $8.23 ; \mathrm{N}, 6.50 ; \mathrm{O}, 22.28 ; \mathrm{S}, 14.88$. Found: $\mathrm{C}, 45.58 ; \mathrm{H}, 3.52 ; \mathrm{Cl}$, $8.21 ; \mathrm{N}, 6.51 ; 0,22.26 ; \mathrm{S}, 14.86$. Overall yield $35 \%$.

5.2.27.7. Compound 81. Amorphous solid- ${ }^{1} \mathrm{H} \quad \mathrm{NMR}$ $\left(300 \mathrm{MHz}\right.$, DMSO- $\left.d_{6}\right): \delta 2.70(\mathrm{dd}, 1 \mathrm{H}, J=7.6,10.8 \mathrm{~Hz}), 3.10(\mathrm{dd}$, $1 \mathrm{H}, J=3.2,10.8 \mathrm{~Hz}), 4.36(\mathrm{~d}, 1 \mathrm{H}, J=10.3 \mathrm{~Hz}), 4.66-4.75(\mathrm{~m}, 2 \mathrm{H})$, 7.05-7.14 (m, 2H), 7.18-7.36 (m, 4H), 7.86-7.93 (m, 2H), $8.75(\mathrm{~s}$ $1 \mathrm{H}), 8.87(\mathrm{~s}, 1 \mathrm{H})$. LC-MS (ESI) $\left(\mathrm{H}_{2} \mathrm{O} / \mathrm{CH}_{3} \mathrm{CN}, 1 \% \mathrm{TFA}\right) \mathrm{m} / \mathrm{z}$ (\%): 399.1 $\left(\mathrm{MH}^{+}, 100\right), \mathrm{C}_{16} \mathrm{H}_{15} \mathrm{FN}_{2} \mathrm{O}_{5} \mathrm{~S}_{2}$ : 398.4. Specific optical rotation $[\alpha]_{\mathrm{D}}^{25}$ -18 (c 0.07, $\mathrm{CH}_{3} \mathrm{OH}$ ). Anal Calcd for $\mathrm{C}_{16} \mathrm{H}_{15} \mathrm{FN}_{2} \mathrm{O}_{6} \mathrm{~S}_{2}$ : C, 46.37; $\mathrm{H}$, 3.65; F, 4.58; N, 6.76; O, 23.16; S, 15.47. Found: $\mathrm{C}_{16} \mathrm{H}_{15} \mathrm{FN}_{2} \mathrm{O}_{6} \mathrm{~S}_{2}$ : C, 46.42; H, 3.65; F, 4.57; N, 6.78; O, 23.20; S, 15.45. Overall yield $30 \%$.

5.2.28. General procedures for synthesis of oxidized derivatives 41

Example: Synthesis of 41a.

MCPBA (31 $\mathrm{mg}, 0.17 \mathrm{mmol}$ ) in $4 \mathrm{ml}$ of dry DCM was added to a DCM pre-swollen $40 a(0.13 \mathrm{mmol})$ at $0{ }^{\circ} \mathrm{C}$. After rocking for $27 \mathrm{~h}$ at room temperature, the resin was filtered and washed with DCM $(\times 2)$, DMF $(\times 2)$, DCM $(\times 2)$ and TBME $(\times 2)$ and finally dried in vacuo.

\subsubsection{General procedures for synthesis of oxidized derivatives 42}

Example: Synthesis of 42a.

MCPBA (37 mg, $0.213 \mathrm{mmol}$ ) in $4 \mathrm{ml}$ of dry DCM was added to a DCM pre-swollen $41 \mathrm{a}(0.04 \mathrm{mmol})$ at $0{ }^{\circ} \mathrm{C}$. After rocking for $27 \mathrm{~h}$ at room temperature, the resin was filtered and washed with DCM $(\times 2)$, DMF $(\times 2)$, DCM $(\times 2)$ and TBME $(\times 2)$ and finally dried in vacuo.

\subsubsection{General procedures for cleavage of hydroxamate derivatives 9 and 10}

We follow the same procedure described for $\mathbf{8 a}$.

5.2.30.1. Compound 9a. Amorphous solid- ${ }^{1} \mathrm{H} \quad \mathrm{NMR}$ $\left(300 \mathrm{MHz}, \mathrm{DMSO}-d_{6}\right): \delta 2.96(\mathrm{dd}, 1 \mathrm{H}, J=3.8,13.5 \mathrm{~Hz}), 3.17(\mathrm{dd}$, $1 \mathrm{H}, J=8.7,13.5 \mathrm{~Hz}), 4.17(\mathrm{~d}, 1 \mathrm{H}, J=11.9 \mathrm{~Hz}), 4.72(\mathrm{dd}, 1 \mathrm{H}, J=3.8$, $8.7 \mathrm{~Hz}), 5.30(\mathrm{~d}, 1 \mathrm{H}, J=11.9 \mathrm{~Hz}), 7.42-7.58(\mathrm{~m}, 3 \mathrm{H}), 7.79(\mathrm{~d}, 2 \mathrm{H}$, $J=7.0 \mathrm{~Hz}$ ), $7.97(\mathrm{~m}, 4 \mathrm{H}), 9.12(\mathrm{~s}, 1 \mathrm{H}), 10.89$ (s, 1H). LC-MS (ESI) $\left(\mathrm{H}_{2} \mathrm{O} / \mathrm{CH}_{3} \mathrm{CN}, 1 \%\right.$ TFA) $\mathrm{m} / \mathrm{z}(\%): 381.1\left(\mathrm{MH}^{+}, 100\right), \mathrm{C}_{16} \mathrm{H}_{16} \mathrm{~N}_{2} \mathrm{O}_{5} \mathrm{~S}_{2}$ : 380.4. Specific optical rotation $[\alpha]_{\mathrm{D}}^{25}-159$ (c 0.07, $\left.\mathrm{CH}_{3} \mathrm{OH}\right)$. Anal. Calcd for $\mathrm{C}_{16} \mathrm{H}_{16} \mathrm{~N}_{2} \mathrm{O}_{6} \mathrm{~S}_{2}: \mathrm{C}, 48.47 ; \mathrm{H}, 4.07 ; \mathrm{N}, 7.07 ; \mathrm{O}, 24.21 ; \mathrm{S}$, 16.18. Found: C, 48.35; H, 4.06; N, 7.05; O, 24.16; S, 16.14. Overall yield $17 \%$. 
5.2.30.2. Compound 10a. Amorphous solid- ${ }^{1} \mathrm{H}$ NMR $\left(300 \mathrm{MHz}\right.$, DMSO- $\left.d_{6}\right): \delta 3.51-3.64(\mathrm{~m}, 2 \mathrm{H}), 4.30(\mathrm{~d}, 1 \mathrm{H}, J=$ $12.4 \mathrm{~Hz}), 4.91(\mathrm{~d}, 1 \mathrm{H}, J=12.4 \mathrm{~Hz}), 5.10(\mathrm{dd}, 1 \mathrm{H}, J=4.9,8.7 \mathrm{~Hz})$, $7.42-7.58(\mathrm{~m}, 3 \mathrm{H}), 7.78$ (d, 2H, J=7.0 Hz), $7.96(\mathrm{~m}, 4 \mathrm{H}), 9.12$ $(\mathrm{s}, 1 \mathrm{H}), 10.89(\mathrm{~s}, 1 \mathrm{H})$. LC-MS (ESI) $\left(\mathrm{H}_{2} \mathrm{O} / \mathrm{CH}_{3} \mathrm{CN}, 1 \% \mathrm{TFA}\right) \mathrm{m} / z(\%)$ : $397.2\left(\mathrm{MH}^{+}, 100\right), \mathrm{C}_{16} \mathrm{H}_{16} \mathrm{~N}_{2} \mathrm{O}_{6} \mathrm{~S}_{2}$ : 396.4 Specific optical rotation $[\alpha]_{D}^{25}-46\left(c 0.05, \mathrm{CH}_{3} \mathrm{OH}\right)$. Anal. Calcd for $\mathrm{C}_{6} \mathrm{H}_{16} \mathrm{~N}_{2} \mathrm{O}_{7} \mathrm{~S}_{2}$ : C, 46.59; H, 3.91; N, 6.79; O, 27.15; S, 15.55. Found: C, 46.65; H, 3.90; N, $6.80 ; 0,27.21 ; \mathrm{S}, 15.59$. Overall yield $12 \%$.

5.2.30.3. Compound 10k. Amorphous solid $-{ }^{1} \mathrm{H} \quad \mathrm{NMR}$ $\left(300 \mathrm{MHz}\right.$, DMSO- $\left.d_{6}\right): \delta 3.24-3.33(\mathrm{~m}, 1 \mathrm{H}), 3.51-6.66(\mathrm{~m}, 1 \mathrm{H})$, $4.41(\mathrm{~d}, 1 \mathrm{H}, J=12.5 \mathrm{~Hz}$ ), 4.64 (dd, $1 \mathrm{H}, J=6.5,8.12 \mathrm{~Hz}), 4.95$ (d, $1 \mathrm{H}, J=13.0 \mathrm{~Hz}), 7.13-7.24(\mathrm{~m}, 4 \mathrm{H}), 7.52(\mathrm{~d}, 2 \mathrm{H}, J=9.2 \mathrm{~Hz}), 7.94$ (d, $4 \mathrm{H}, J=9.2 \mathrm{~Hz}), 9.27$ (s, 1H), 11.03 (s, 1H). LC-MS (ESI) $\left(\mathrm{H}_{2} \mathrm{O} /\right.$ $\mathrm{CH}_{3} \mathrm{CN}, 1 \%$ TFA) $\mathrm{m} / z$ (\%): $447.1\left(\mathrm{MH}^{+}, 60\right), \mathrm{C}_{16} \mathrm{H}_{15} \mathrm{ClN}_{2} \mathrm{O}_{7} \mathrm{~S}_{2}: 446.8$. Specific optical rotation $[\alpha]_{\mathrm{D}}^{25}-60\left(c 0.05, \mathrm{CH}_{3} \mathrm{OH}\right)$. Anal Calcd for $\mathrm{C}_{16} \mathrm{H}_{15} \mathrm{ClN}_{2} \mathrm{O}_{8} \mathrm{~S}_{2}$ : C, 41.52; H, 3.27; $\mathrm{Cl}, 7.66 ; \mathrm{N}, 6.05 ; \mathrm{O}, 27.65 ; \mathrm{S}$, 13.85. Found: C, 41.48; H, 3.26; Cl, 7.63; N, 6.03; O, 27.59; S, 13.81. Overall yield $9 \%$.

\subsection{Enzymatic assay}

The enzymatic assays for MMP1, 2, 3, 8, 9, 12, and 14 were based upon the protocol described by Knight et al. ${ }^{29}$ Active catalytic domains of MMP1, 3, 8, 9, 12, and 14 were purchased from Biomol (Biomol International, Plymouth Meeting) while proMMP2 (from R\&D Systems, Inc.) was activated by incubation for $1 \mathrm{~h}$ at $37^{\circ} \mathrm{C}$ with aminophenylmercuric acetate (APMA) $1 \mathrm{mM}$ final concentration solution.

All enzymatic solutions were then diluted in Tris- $\mathrm{HCl}$ assay buffer (Tris/HCl $50 \mathrm{mM}, \mathrm{NaCl} 0.1 \mathrm{M}, \mathrm{CaCl}_{2} 10 \mathrm{mM}, 0.05 \%$ Brij 35, pH $7.5)$ in order to obtain final concentrations of the enzymes used in the assay included between 0.5 and $3 \mathrm{nM}$.

The fluorogenic substrate was Mca-Pro-Leu-Gly-Leu-Dpa-AlaArg- $\mathrm{NH}_{2}{ }^{30}$ (Biomol Research Laboratories, Inc.) for all tested MMP. The final substrate concentrations performed in assays conditions were in the range of $2-7 \mu \mathrm{M}$.

Test compounds were dissolved in dimethyl sulfoxide (DMSO) and diluted with test buffer solution so that no more than $1 \%$ DMSO was present. Test compound and enzymes were added to each well of a 96-well plate and allowed to equilibrate for $1 \mathrm{~h}$ at $37^{\circ} \mathrm{C}$ prior to the addition of substrate. Determinations of fluorescence was performed using a Varian Cary Eclipse spectrofluorimeter $\left(\lambda_{\mathrm{ex}} 328 \mathrm{~nm}, \lambda_{\mathrm{em}} 393 \mathrm{~nm}\right)$, respectively after addiction of fluorogenic substrate (T0) and after $3 \mathrm{~h}$ incubation at $37^{\circ} \mathrm{C}(\mathrm{T} 3 \mathrm{~h})$.

Inhibitors potency was evaluated from the amount of substrate cleavage calculated from fluorescence delta between the two measurements $\mathrm{T} 0$ and $\mathrm{T} 3 \mathrm{~h}$, using a range of test compound concentrations (at least six concentrations, each one in duplicate).

From the resulting dose-response curve $\mathrm{IC}_{50}$ values (the concentration of inhibitor required to inhibit $50 \%$ of the enzyme activity) were calculated from a three-parameter logistic fit of the data (GraphPad Prism version 4.00 for Windows, GraphPad Software, San Diego California USA).

\section{Acknowledgments}

The authors thank Drs. Tatiana Guzzo and Teresa Fabiola Miscioscia for their essential support. This work was financed by MIUR (Ministero dell'Istruzione, dell'Università e della Ricerca).

\section{References and notes}

1. Coussens, L. M.; Werb, Z. Chem. Biol. 1996, 3, 895.

2. Whittaker, M.; Floyd, C. D.; Brown, P.; Gearing, A. J. H. Chem. Rev. 1999, 99, 2735.

3. Baker, A. H.; Edwards, D. R.; Murphy, G. J. Cell. Sci. 2002, 115, 3719.

4. Li, N. G.; Shi, Z. H.; Tang, Y. P.; Duan, J. A. Curr. Med. Chem. 2009, 16, 3805.

5. Aureli, L.; Gioia, M.; Cerbara, I.; Monaco, F.; Fasciglione, G. F.; Marini, S.; Ascenzi, P.; Topai, A.; Coletta, M. Curr. Med. Chem. 2008, 15, 2192.

6. Oshitari, T.; Okuyama, Y.; Miyata, Y.; Kosano, H.; Takahashi, H.; Natsugari, H. Bioorg. Med. Chem. 2011, 19, 7085.

7. Wang, J.; Medina, C.; Radomski, M. W.; Gilmer, J. F. Bioorg. Med. Chem. 2011, 19, 4985.

8. Dorman, G.; Kocsis-Szommer, K.; Spadoni, C.; Ferdinandy, P. Recent Pat. Cardiovasc. Drug Discov. 2007, 2, 186.

9. Renkiewicz, R.; Qiu, L.; Lesch, C.; Sun, X.; Devalaraja, R.; Cody, T.; Kaldjian, E.; Welgus, H.; Bagagi, V. Arthritis Rheum. 2003, 48, 1742.

10. Pavlaki, M.; Zucker, S. Cancer Met. Rev. 2003, 22, 177.

11. Coussens, L. M.; Fingleton, B.; Matrisian, L. M. Science 2002, 295, 2387.

12. Overall, C. M.; Kleifeld, O. Nat. Rev. Cancer 2006, 6, 227.

13. Nuti, E.; Tuccinardi, T.; Rossello, A. Curr. Pharm. Des. 2007, 13, 2087.

14. Haas, T. L. Can. J. Physiol. Pharmacol. 2005, 83, 1.

15. Sluijter, J. P.; de Kleijn, D. P.; Pasterkamp, G. Cardiovasc. Res. 2006, 69, 595.

16. Deryugina, E. I.; Quigley, J. P. Cancer Metastasis Rev. 2006, 25, 9.

17. Overall, C. M.; Kleifeld, O. Br. J. Cancer 2006, 94, 941.

18. Higashi, S.; Miyazaki, K. Biol. Chem. 2008, 283, 10068.

19. Berman, H. M.; Westbrook, J.; Feng, Z.; Gilliland, G.; Bhat, T. N.; Weissig, H.; Shindyalov, I. N.; Bourne, P. E. Nucleic Acids Res. 2000, 28, 235.

20. Shindyalov, I. N.; Bourne, P. E. Protein Eng. 1998, 11, 739.

21. MOE: Chemical Computing Group Inc. (2003): 1010 Sherbrooke Street West, Suite 910, Montreal, H3A 2R7, Canada.

22. Lipinski, C. A.; Lombardo, F.; Dominy, B. W.; Feeney, P. J. Adv. Drug Deliv. Rev. 2001, 46, 3.

23. Xu, J.; Stevenson, J. J. Chem. Inf. Comput. Sci. 2000, 40, 1177.

24. Oprea, T. I. J. Comput. Aided Mol. Des. 2000, 14, 251.

25. Kiyama, R.; Tamura, Y.; Watanabe, F.; Tsuzuki, H.; Ohtani, M.; Yodo, M. J. Med. Chem. 1999, 42, 1723.

26. DeLano, W.L. The PyMOL molecular graphics system. 2002 (http:// www.pymol.org).

27. Kaiser, E.; Colescott, R. L.; Bossinger, C. D.; Cook, P. I. Anal. Biochem. 1970, 34, 595.

28. Mellor, S. L.; McGuire, C.; Chan, W. C. Tetrahedron Lett. 1997, 38, 3311.

29. Knight, C. G.; Willenbrock, F.; Murphy, G. FEBS Lett. 1992, 296, 263.

30. Will, H.; Atkinson, S. J.; Butler, G. S.; Smith, B.; Murphy, G. J. Biol. Chem. 1996, $271,17119$. 